\title{
A Review of the Fossil Record of Turtle Reproduction: Eggs, Embryos, Nests and Copulating Pairs
}

\section{Authors: Daniel R. Lawver and Frankie D. Jackson}

This is a postprint of an article that originally appeared in Bulletin of the Peabody Museum of Natural History on October 2014. ( 2014 Peabody Museum of Natural History, Yale University. All rights reserved. $\cdot$ http://peabody.yale.edu

Lawver, Daniel R., and Frankie D. Jackson. "A Review of the Fossil Record of Turtle Reproduction: Eggs, Embryos, Nests and Copulating Pairs." Bulletin of the Peabody Museum of Natural History 55, no. 2 (October 2014): 215-236. doi 10.3374/014.055.0210.

Made available through Montana State University's $\underline{\text { ScholarWorks }}$ 


\title{
A Review of the Fossil Record of Turtle Reproduction: Eggs, Embryos, Nests and Copulating Pairs
}

\author{
Daniel R. Lawver and Frankie D. Jackson \\ Department of Earth Sciences, Montana State University, P.O. Box 173480, Bozeman MT 59717-3480 USA \\ Corresponding author:_email: danlawver@gmail.com \\ -email: frankiej@montana.edu
}

\begin{abstract}
The fossil record of turtle reproduction (e.g., eggs, embryos, nests and copulating pairs) is relatively poor compared with that of dinosaurs. This record extends from the Middle Jurassic to the Pleistocene, and specimens are known from every continent except Antarctica. Fossil turtle eggs are recognized as body fossils, and confident taxonomic identification at the genus or species level is dependent on embryos preserved within fossil eggs or by eggs found within a gravid female. Cladistic analysis of egg and eggshell characters demonstrates a high degree of homoplasy, and only a few characters provide a strong phylogenetic signal. Taphonomic studies of fossil turtle eggs are rare but can elucidate size and number of eggs produced by extinct taxa. Pathological fossil turtle eggs are known from a few localities and provide information about physiological or environmental stresses experienced by the gravid female. Fossil turtle eggs are relatively abundant in Asia, Europe and North America but are poorly represented in Gondwana. An ootaxonomic review of fossil turtle eggs shows that of 15 named ootaxa, 8 are nomina valida, 5 are nomen nudum and 2 are junior synonyms of other ootaxa.
\end{abstract}

KEYWORDS

Testudines, paleoology, Testudoolithidae, Testudoflexoolithidae

\section{Introduction}

Turtles are some of the most distinct animals living today and possess unique anatomical and physiological characters, also in regard to their reproduction. For example, unlike all other living amniotes, turtles produce eggs composed of the mineral aragonite, rather than calcite (Hirsch 1983). When preserved in the rock record, this mineral composition allows definitive assignment of fossil eggs and eggshell to Testudines or their stem lineage. Indeed, based on this unique eggshell composition, some authors suggest that hardshelled eggs evolved independently in turtles from all other amniotes (Carpenter 1999; Sander 2012).

Fossil turtle eggs are known from every continent except Antarctica and range in age from the Jurassic to the Pleistocene. The oldest described turtle eggs were collected from the Middle Jurassic of England (Carruthers 1871). This corresponds roughly to the age of the turtle crown, as estimated from the fossil record (Danilov and Parham 2006; Joyce 2007; Anquetin et al. 2009) or through molecular calibration studies (Joyce, Parham et al. 2013). Considering that the oldest known fully shelled amniote ("turtle" in common parlance), Proterochersis robusta, is known from the Late Triassic (Fraas 1913; Joyce, Schoch et al. 2013), it is apparent that the presence of aragonitic eggs is either a feature that was acquired just before the split of the crown group, or that a substantial gap exists in the fossil record. In contrast to nonavian dinosaurs, which receive most of the attention in paleoological studies, modern analogs exist for extinct turtle eggs, embryos, nests and copulating pairs. In addition, extant turtles provide information about growth and development, physiology, anatomy and paleoecology that are necessary for more accurate interpretations of fossil specimens 
and localities. For institutional abbreviations see Appendix 1. Named turtle oogenera are listed in Appendix 2.

\section{Methods Used in the Study of Fossilized Eggs}

Standard preparation techniques for the study of fossil eggshell include examination of thin sections with a polarized light microscope (Quinn 1994) and scanning electronic microscope, the latter typically being equipped with energy dispersive X-ray and backscatter electron imaging (Tyler 1969; Erben et al. 1979; Carpenter 1999; Jackson et al. 2002; Schweitzer et al. 2002). Depending on the purpose of the study, additional analyses might include cathodoluminescence (England et al. 2006; Grellet-Tinner et al. 2010; Fernández and Matheos 2011), epifluorescence microscopy (Jackson et al. 2010) and X-ray diffraction (Jackson et al. 2002). Structural attributes of eggshell (shell thickness, pore width) are typically measured with image analysis software. Computed tomography and phase contrast synchrotron microtomography allow high-resolution imaging of eggs, which is necessary for identification of in ovo embryonic remains, while avoiding mechanical preparation and potential damage to the specimens (Fernandez et al. 2012). Finally, two recent studies of fossil eggs also include electron backscatter diffraction and orientation contrast imaging to "map" the orientation of crystal growth (Grellet-Tinner et al. 2012; Moreno-Azanza, Mariani et al. 2013).

\section{Physical Attributes of Turtle Eggs}

Turtle eggs range from spherical in large-bodied species to elongate in relatively small-bodied species (Ewert 1979; Iverson and Ewert 1991). Intra- and interspecific variation in egg size, shape and number of eggs per clutch characterizes modern turtle taxa. For example, younger, smaller females might lay fewer and smaller eggs per clutch than older, larger females (Kuchling 1999). Clutch size ranges from a single large egg in Platemys platycephala to more than 100 eggs in the leatherback sea turtle (Dermochelys coriacea; Ernst and Barbour 1989). Interestingly, D. coriacea lays both large and small eggs in a single clutch. The small, yolkless eggs are thought to result from excess albumen (Spotila 2004) or, alternatively, to act as spacers between the larger, viable eggs thereby increasing gas exchange (Gulko and Eckert 2004).

Turtle eggshell consists of a single layer of shell units composed of needle-like aragonite crystals that originate from an organic core within the shell membrane. The degree of mineralization varies widely among turtle eggs and includes pliable (chelonioids, emydids and some pleurodires), semipliable (chelydrids), and rigid-shelled eggs (carettochelyids, geoemydids, kinosternoids, testudinids and trionychids). This variation in eggshell mineralization corresponds to variation in the height to width ratios of the shell units and whether the shell units are loosely or tightly spaced and interlocking in structure (Figure 1). The tightly interlocking structure of rigid-shelled eggs enhances their potential for preservation in the fossil record (Hirsch 1983).

\section{Classification of Fossil Turtle Eggs}

Early studies often assigned fossil eggs to turtles based on their size, spherical shape and eggshell texture (Buckman 1859; Meyer 1860; Carruthers 1871; Hay 1908; Van Straelen 1928), but 'Oolithes' bathonicae Buckman, 1859, was the only named taxon well into the 20th century. Hirsch (1983) was the first to compare the microstructure of fossil eggs with that of modern turtle eggs, emphasizing the importance of polarized light microscopy and scanning electron microscopy. Hirsch (1996) later extended the parataxonomy developed for classifying dinosaur eggs to include fossil turtle eggs and started naming fossil turtle oospecies using microstructure characteristics as the basis of his diagnoses. Based on the degree of eggshell mineralization, he established two morphotypes under the Testudoid basic type of eggshell structure: (1) Spheruflexibilis, for soft or pliable eggs; and (2) Spherurigidis, for rigid eggshell, spheru referring to the spherulitic ultrastructure of the shell units. These morphotypes are distinguished by the height to width ratio of their shell units and whether the shell units are tightly interlocking. A single oofamily corresponds to each morphotype, namely Testudoolithidae and Testudoflexoolithidae, respectively. Currently, at least five valid oogenera and eight valid oospecies have been established for fossil turtle eggs (Table 1). 
A

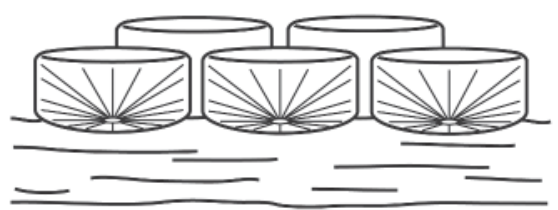

C

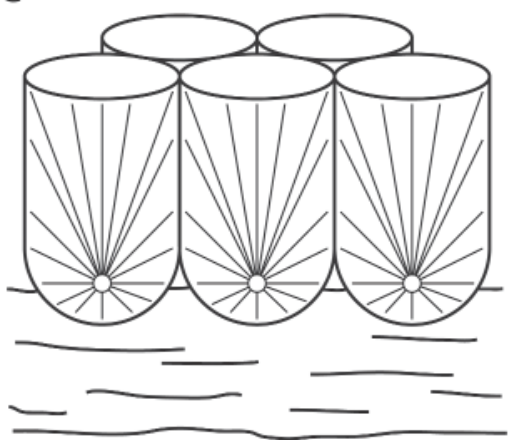

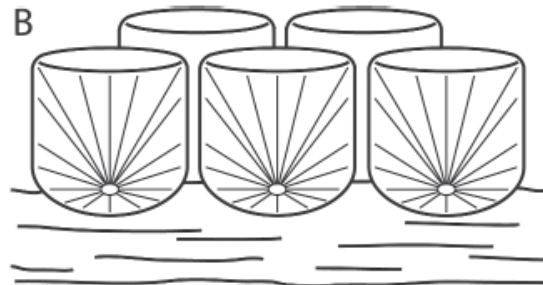

D

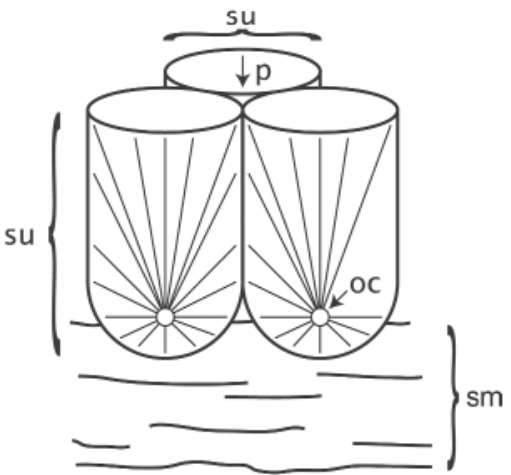

FIGURE 1. Eggshell microstructure of fossil and modern turtle eggs. A, Pliable-shelled turtle eggs with shell units wider than tall. B, Semipliable turtle eggs with shell units as wide as tall. C, Rigid-shelled turtle eggs with shell units taller than wide. D, Turtle eggshell structure. Abbreviations: oc, organic core; p, pore; sm, shell membrane; su, shell unit. Modified from Hirsch (1983, fig. 2).

It is important to note that Hirsch's (1996) attempt to build an internally coherent nomenclatural system for turtle eggshells that is consistent with the International Code of Zoological Nomenclature (ICZN) failed from the beginning because his scheme demands referral of the previously named oospecies Oolithes bathonicae Buckman, 1859 to the new oogenus Testudoflexoolithus. Following the rules of the ICZN (ICZN 1999), Testudoflexoolithus is the objective junior synonym of Oolithes and should not be used. However, given that Hirsch's (1996) nomenclatural system has be utilized consistently over the course of the past two decades (e.g., Kohring 1999b; Jackson et al. 2008; Barta et al. 2014), we herein maintain nomenclatural stability by maintaining this system, while formally acknowledging the apparent break with the ICZN.

\section{Taxonomic Assignment of Fossil Turtle Eggs}

Many authors have attempted to identify the species of turtle that potentially laid a given fossil egg (Gergens 1860; Meyer 1860; Hummel 1929; Kohring 1993; Gaffney 1996; Azevedo et al. 2000).
However, definitive identification requires embryonic remains or eggs that occur within a gravid female because eggshells generally do not provide enough characters to allow diagnosing species (Hirsch 1989). Therefore, all identifications that lack these criteria should be treated with suspicion. In addition, embryos often lack the diagnostic features necessary to identify fossil eggs beyond the genus level. For example, McGee (2012) identified fossil turtle eggs with embryos from Canada as originated from Adocus based on eggshell microstructure and morphology of the embryonic bones. However, she refrained from identifying the specimens to a particular Adocus species because diagnostic morphologies were not present in the embryos, likely due to their early ontogenetic stage. Fossil gravid turtles can potentially provide species-level identification of eggs, depending on the presence of autapomorphic characters and quality of adult preservation. For example, eggs were discovered in an undescribed Canadian specimen of Basilemys variolosa after the carapace was inadvertently damaged (Braman and Brinkman 2009). Although fossil gravid turtles can provide higher levels of taxonomic identification, incomplete egg formation at the time 


\begin{tabular}{|c|c|c|c|c|c|}
\hline $\begin{array}{c}\text { Ootaxon } \\
\text { and holotype }\end{array}$ & Material & $\begin{array}{l}\text { Egg } \\
\text { shape }\end{array}$ & $\begin{array}{l}\text { Length by } \\
\text { width (mm) }\end{array}$ & $\begin{array}{c}\text { Eggshell } \\
\text { thickness } \\
(\mathrm{mm})\end{array}$ & $\begin{array}{l}\text { Shell unit } \\
\text { (height: } \\
\text { width) }\end{array}$ \\
\hline $\begin{array}{l}\text { Testudoflexoolithus agassizi } \\
\text { MCZ 2810/HEC } 49\end{array}$ & $\begin{array}{l}\text { Eggshell } \\
\text { fragments }\end{array}$ & - & - & $0.06-0.1$ & $1: 1$ or $2: 3$ \\
\hline $\begin{array}{l}\text { Testudoflexoolithus bathonicae } \\
\text { MB(NH)37983/HEC } 186\end{array}$ & $\begin{array}{l}\text { An egg } \\
\text { embedded } \\
\text { in matrix }\end{array}$ & Ellipsoidal & $48 \times 26$ & $0.2-0.25$ & $1: 1$ \\
\hline $\begin{array}{l}\text { Chelonoolithus braemi } \\
\text { Guimarota } 98-2\end{array}$ & $\begin{array}{l}\text { Eggshell } \\
\text { fragments }\end{array}$ & - & - & 0.2 & $1: 1$ \\
\hline $\begin{array}{l}\text { Emydoolithus laiyangensis } \\
\text { IVPP V18544 }\end{array}$ & $\begin{array}{c}\text { A nearly } \\
\text { complete egg }\end{array}$ & Elongate & $91 \times 22$ & $0.4-0.5$ & $2: 1$ to $5: 1$ \\
\hline Haininchelys curiosa & $\begin{array}{l}\text { Eggshell } \\
\text { fragments }\end{array}$ & - & - & $0.25-0.3$ & $1.2: 1$ to $2.3: 1$ \\
\hline Testudoolithus hirschi & $\begin{array}{l}\text { Eggshell } \\
\text { fragments }\end{array}$ & - & - & 0.15 & $3: 1$ \\
\hline $\begin{array}{l}\text { Testudoolithus jiangi } \\
\text { ZMNH M8713 }\end{array}$ & $\begin{array}{l}\text { A clutch } \\
\text { of } 23 \text { eggs }\end{array}$ & Spherical & $35 \times 52$ & $0.7-1.0$ & $2.5: 1$ to $3: 1$ \\
\hline $\begin{array}{l}\text { Testudoolithus rigidus } \\
\text { UCM 55806/ HEC } 425\end{array}$ & $\begin{array}{l}\text { Half of } \\
\text { an egg }\end{array}$ & Spheroidal & $42 \times 47$ & $0.22-0.24$ & $2: 1$ \\
\hline
\end{tabular}

of death results in thinner than normal eggshell (Zelenitsky et al. 2008; Knell et al. 2011) that could complicate identification.

In addition to incorrect taxonomic identification of fossil turtle eggs, some older literature refers to megaloolithid dinosaur eggs as "testudoid" (Sochava 1971; Erben et al. 1979). These studies explicitly state that the eggs in question are those of dinosaurs and that the term does not reflect taxonomic identification. The word "testudoid" refers to the gross similarity between the eggshell structure of megaloolithid and modern turtle eggs, thus resulting in misleading terminology. Similarly, Mikhailov (1997) provides identical descriptions for both Discretispherulitic (megaloolithid) and testudoid eggs. However, turtle eggs are composed of aragonite and have a smaller overall egg size and generally a smooth external surface compared with megaloolithid eggs.

\section{Fossil Eggs: Trace Compared with Body Fossils}

Fossil eggs are interesting because they do not strictly conform to the traditional definitions of either trace or body fossils but rather are somewhere in between these categories. Some authors (Jain 1989; Lockley and Gillette 1989; Bray and Hirsch 1998) regard fossil eggs and eggshell as trace fossils. This category is defined as any evidence of an organism, excluding body parts, and characterized by organismal behavior preserved in a substrate, such as footprints, burrows, feeding marks and coprolites (Martin 2013). Further, Bertling et al. (2006) suggests that trace fossils should be categorized by their morphology alone and should not be influenced by the taxonomic identity of the trace maker; however, others (Simpson 1975; Lockley and Gillette 1989) suggests that a certain level of taxonomic identification is possible.

On the other hand, Martin (2001) views fossil eggs as the preserved remains of an organism itself, and therefore, they are body fossils. Here we argue that, of the views presented, the evidence for eggs being body fossils is most convincing because eggshell, similar to the shell of invertebrates, is an essential part of the developing organism (Martin 2001). The chorioallantoic membrane provides a direct connection between the embryo and the egg, which allows for aerobic metabolism and the uptake of calcium by the embryo from the eggshell (Carpenter 1999). In addition, the aragonite structure of the eggshell is under direct genetic control (Rodriguez-Navarro et al. 2007; Dunn et al. 2012), and the embryo, yolk, albumin, membranes and mineralized eggshell form a single unit. As such, fossil eggs and eggshell offer insight into some of the earliest 
ontogenetic stages of extinct organisms and are occasionally augmented by data from identifiable embryonic remains and gravid females. In contrast, the preserved structure of a nest and its egg arrangement are trace fossils that provide evidence of parental behavior in the preparation of a suitable environment for embryonic development, sometimes including manipulation of the eggs by the parent (Varricchio et al. 1999).

\section{Cladistic Analysis of Eggs and Eggshell Characters}

Several studies advocate the usefulness of egg and eggshell characters in determining phylogenetic relationships among extinct taxa (Mikhailov 1992; Zelenitsky and Modesto 2003; GrelletTinner and Chiappe 2004; Varricchio and Jackson 2004; Grellet-Tinner 2006; Jin et al. 2010). However, such analyses are rarely applied to extant taxa in order to test the validity of this approach.

Winkler (2006) mapped eggshell characters onto a composite phylogeny of extant pleurodiran turtles (12 taxa and 13 characters). This study suggests a high degree of homoplasy in the eggs and eggshells of these taxa, and only 3 characters provide a phylogenetic signal. However, the scope of her study was narrow because she only examined pleurodiran turtles from two families (e.g., Chelidae and Pelomedusidae), both of which lay hard-shelled eggs.

Lawver (2012) more recently conducted an expanded cladistic analysis using egg and eggshell characters to assess the phylogenetic relationships of multiple turtle clades (e.g., Chelidae, Kinosternidae, Dermatemydidae, Trionychidae, Bataguridae and Testudinidae) within Testudines and also included a fossil turtle egg from the Upper Cretaceous (Campanian) Judith River Formation of Montana, which likely represents an Adocus sp. egg because of its microstructural similarities to those from an in situ clutch discovered in Alberta, Canada (Zelenitsky et al. 2008). The resulting strict consensus tree contains a fully resolved archosaurian clade with a sister taxon relationship to Testudines. Within Testudines, a clade consisting of the Trionychidae and the fossil turtle egg is resolved, but all other ingroup taxa form a large polytomy. If the Adocus sp. identification of the fossil is confirmed, it would suggest that some egg and eggshell characters are potentially informative for diagnosing a clade consisting of trionychids and Adocus sp. This clade is otherwise well supported by previous morphological analyses (Gaffney and Meylan 1988; Meylan and Gaffney 1989; Joyce 2007). The results of the study by Lawver (2012) are otherwise consistent with Winkler's (2006) conclusions by demonstrating a high degree of homoplasy in turtle egg characters and only limited use in diagnosing turtle clades.

\section{Nests}

Most descriptions of fossil turtle eggs focus on isolated specimens rather than in situ eggs and clutches, thus providing little or no information about site taphonomy. Currently, descriptions of in situ material include only the three specimens discussed subsequently.

Zelenitsky et al. (2008) describes an in situ Adocus sp. egg clutch and gravid female, respectively, from the Upper Cretaceous (Campanian) Oldman and Dinosaur Park formations in Alberta, Canada. The in situ clutch covers an oval-shaped area of $480 \mathrm{~mm}$ by $350 \mathrm{~mm}$ and consists of approximately 26 eggs. Zelenitsky et al. (2008) interpreted the sandy siltstone surrounding the clutch as well-drained levee deposits. Twenty-four of the 26 rigid-shelled eggs are crushed, whereas 2 relatively uncrushed specimens measure about $40 \mathrm{~mm}$ by $42 \mathrm{~mm}$ in diameter. The eggshell measures 730 to $810 \mu \mathrm{m}$ thick.

The second specimen consists of a gravid adult that displays a crushed carapace $310 \mathrm{~mm}$ wide by $405 \mathrm{~mm}$ long. The carapace contained at least five $35 \mathrm{~mm}$ by $40 \mathrm{~mm}$ rigid-shelled eggs. The eggshells measure 500 to $650 \mu \mathrm{m}$ thick and some preserve permineralized membrane that measures about one-third of the eggshell thickness. The substantially thinner eggshell associated with the gravid female, compared with the in situ clutch, indicates that the eggs were not fully formed but within days of oviposition (Zelenitsky et al. 2008). Zelenitsky et al. (2008) uses the correlation between body size and clutch size among extant turtle species to estimate (1) the carapace length of the female that laid the in situ clutch and (2) the number of eggs produced by the gravid female. The 26 eggs in the in situ clutch suggest an adult carapace length of $495 \mathrm{~mm}$, whereas the gravid female likely produced a smaller clutch of approximately 19 eggs. The 
latter, however, preserved only 5 eggs within the specimen. Rigid eggshell is thought to have evolved independently in turtle clades in response to predation, and the low pore density of Adocus sp. eggs is consistent with low water vapor conductance, which could indicate adaptation in response to dry nesting conditions (Zelenitsky et al. 2008).

Fang et al. (2003) describe two eggs from a turtle clutch from the Lower Cretaceous Tiantai Basin, Zhejiang, China, establishing a new oogenus and oospecies within a new oofamily. Jackson et al. (2008) reassigned the specimens to Testudoolithus jiangi and provided information about the clutch and its paleoecology and depositional environment. These eggs and their rather confusing parataxonomic history are discussed in our "Systematic Paleontology" section. Here, we focus on the clutch and sedimentology of the nesting site.

As typical of many specimens from the Tiantai Basin, the clutch was recovered from a construction site, and its original size remains unknown. In its current condition, the $27 \mathrm{~cm}$ by $47 \mathrm{~cm}$ block contains 23 eggs and 4 additional eggs separated from the block during excavation. Sedimentary structures associated with the clutch confirm its original orientation in the stratum and indicate a low flow regime, typical of fluvial environments that characterize many turtle nesting localities today. In addition, the clutch contains three superimposed layers of eggs, suggesting that the female buried the eggs in a relatively deep, excavated hole. Blue-gray reduction "halos" surrounding the eggs and associated burrow and root traces indicate that pedogenic processes occurred near or below the water table.

Based on comparison of egg shape and size with extant taxa, Jackson et al. (2008) propose that the clutch belonged to a Cretaceous turtle of large body size, possibly comparable to large-bodied extant testudinids turtles. The thick, rigid eggshell and spherical egg shape likely reduced the possibility of lethal desiccation because the greater pore length and reduced surface area retarded water loss during incubation. In addition, the specimen reveals rare evidence of fungal-animal association in the fossil record (Jackson et al. 2009). A single egg on the periphery of the clutch contains fossil fungal structures, suggesting opportunistic fungal invasion after the egg was compromised and prior to subsequent failure of the clutch as a whole.
Bishop et al. (2011) reports a sea turtle nesting trace that included an egg chamber, egg molds, body pit and an adult crawlway from the Late Cretaceous (Maastrichtian) Fox Hills Formation in Elbert County, Colorado. The strata containing the traces consist of (1) basal sandstone with faint horizontal and cross-bedding; (2) a strongly laminated sequence of heavy mineral layers interbedded with bioturbated sands, which in turn were overlain by (3) anatomizing sandstones with scour-flute casts on their bases; and (4) a thin homogenous interval capped by festoon crossbedded sandstone. Bishop et al. (2011) interprets the sequence as representing a forebeach, backbeach and dune field. The sedimentary structures of these nesting traces (Bishop et al. 2011, figs. 13.8 and 13.9) strongly resemble the size and morphology of those produced by modern loggerhead sea turtles at nesting sites monitored by the St. Catherines Island Sea Turtle Conservation Program near Savannah, Georgia (Bishop et al. 2011).

Winkler and Sánchez-Villagra (2006) describe a single layer of abundant turtle eggshells in a coarse, poorly sorted sandy deposit. These eggshells occur within a $600 \mathrm{~m}^{2}$ area at a locality in the Miocene Urumaco sequence of Venezuela. Based on an in situ fragment of an egg, they suggest an elliptical shape and estimate the original size as $56.5 \mathrm{~mm}$ by $43.5 \mathrm{~mm}$. This red oxidized sandstone also contained foraminifera, the ichnofossil Thalassinoides, and small unidentifiable fragments of bivalve shells, possibly of marine origin. Although providing no evidence for their conclusions, Winkler and Sánchez-Villagra (2006) interpret these eggshell fragments as egg "clusters" or "clutches." Further, they conclude that turtles deposited their eggs at a colonial nesting site on a beach directly facing the sea or brackish waters, possibly near a river delta or lagoon. Based on a large, poorly preserved carapace within a few centimeters of a purported egg clutch, they tentatively assign the eggshells to Bairdemys venezuelensis. The lack of a detailed site description warrants caution with the interpretations of this locality.

\section{Pathological Conditions of Eggs}

In extant amniotes that lay hard-shelled eggs, adverse stimuli from physiological or environmental stress occasionally produce prolonged egg retention by the female. One or more eggshell lay- 
ers can be deposited over the retained egg, producing an unusually thick, multilayered eggshell that typically results in embryonic death (Ewert et al. 1984). Among modern taxa, this condition occurs most commonly in turtles, currently reported in 10 species (Jackson and Schmitt 2008). However, reports of similar abnormal conditions in fossil turtle eggshells are rare. Kohring (1998b) reported multilayered turtle eggs from the Miocene of the Czech Republic, and Jackson and Schmitt (2008) document a multilayered egg in a weathered clutch from the Upper Cretaceous (Campanian) Judith River Formation of Montana.

\section{Paleobiogeography}

The temporal and geographic distribution of fossil turtle eggs and eggshell suggest two interesting trends. First, there is a trend for the gradual increase in fossil turtle eggs and eggshell occurrences toward the present. This "pull of the recent" can be explained by the fact that the aragonite composition of turtle eggshell is metastable and therefore is likely to be altered with increasing geologic time. However, some specimens from the Jurassic show relatively unaltered aragonite crystals, whereas specimens from three to four million year rocks are completely altered (Hirsch 1996). This suggests that certain local environments are more suitable for exceptional preservation for longer periods of time. Additionally, certain time periods (Campanian and Albian) show an unexpectedly large number of occurrences. This can be explained by collecting biases toward accessible and highly productive localities of this age, or perhaps the preservation potential was higher for aragonite during this period. An exact mechanism for such preservation is unknown at this time.

The Miocene also shows a large peak of occurrences of fossil turtle eggs and eggshell; however, the Miocene represents $17.5 \mathrm{my}$, which is significantly longer than many other geologic periods. At this time, limited age information for several specimens discussed previously prohibits proper analysis using equilibrated time binning.

Second, the geographic distribution of turtle reproduction in the fossil record shows that the vast majority of specimens come from Laurasian continents, with at least 49 occurrences. In contrast, Gondwanan continents have significantly fewer occurrences (approximately 14) of fossil turtle eggs and eggshell (Appendix 3). This is likely due to collection biases. Trends such as these have also been observed in the temporal and geographic distributions of dinosaurian ootaxa in which the greatest diversity is found in Laurasian continents at the end of the Cretaceous (Varricchio et al. 2011).

\section{Systematic Paleontology}

\section{Valid Ootaxa}

See Appendix 4 for the hierarchical taxonomy of ootaxa as described in this work.

Testudoflexoolithidae Hirsch, 1996

Diagnosis. Eggshell of the taxon Testudoflexoolithidae is diagnosed by the testudoid basic type, the spheruflexibilis morphotype, loosely abutting shell units, pore canals absent or widely spaced between shell units and spheroidal to ellipsoidal egg shape.

\section{Testudoflexoolithus Hirsch, 1996}

Type oospecies. Testudoflexoolithus bathonicae (Buckman, 1859).

Diagnosis. Eggshell of the ootaxon Testudoflexoolithus is diagnosed by loosely abutting shell units, an ellipsoidal egg shape and 0.06 to $0.2 \mathrm{~mm}$ thick eggshell.

\section{Testudoflexoolithus agassizi Hirsch, 1996}

Taxonomic history. Testudoflexoolithus agassizi Hirsch, 1996 (new oospecies).

Type material. MCZ 2810/HEC 49 (holotype), eggshell fragments (Hirsch 1996, fig. 3a-d).

Type locality. Florida, USA (see Figure 2); Florida Oolite, Pleistocene (Hirsch 1996).

Diagnosis. Eggshell of the ootaxon Testudoflexoolithus agassizi is diagnosed by a shell unit height to width ratio of 1:1 to 2:3 and 0.06 to $0.1 \mathrm{~mm}$ thick eggshell. T. agassizi can be distinguished from $T$. bathonicae by a shell thickness that is two or more times thicker.

Comments. The microstructure of Testudoflexoolithus agassizi is very similar to that of the extant sea turtle Lepidochelys kempii, but the egg shape remains unknown (Hirsch 1996). Given the relatively recent age of the fossil and the facies in which they were found, it is plausible that a cheloniid sea turtle produced these specimens. The loosely abutting eggshell units of this oospecies are likely to disassociate from one another after decomposition of the shell membrane. Preservation of this pliable eggshell is therefore rare (Hirsch 1996). Very little locality information is available for this taxon. 


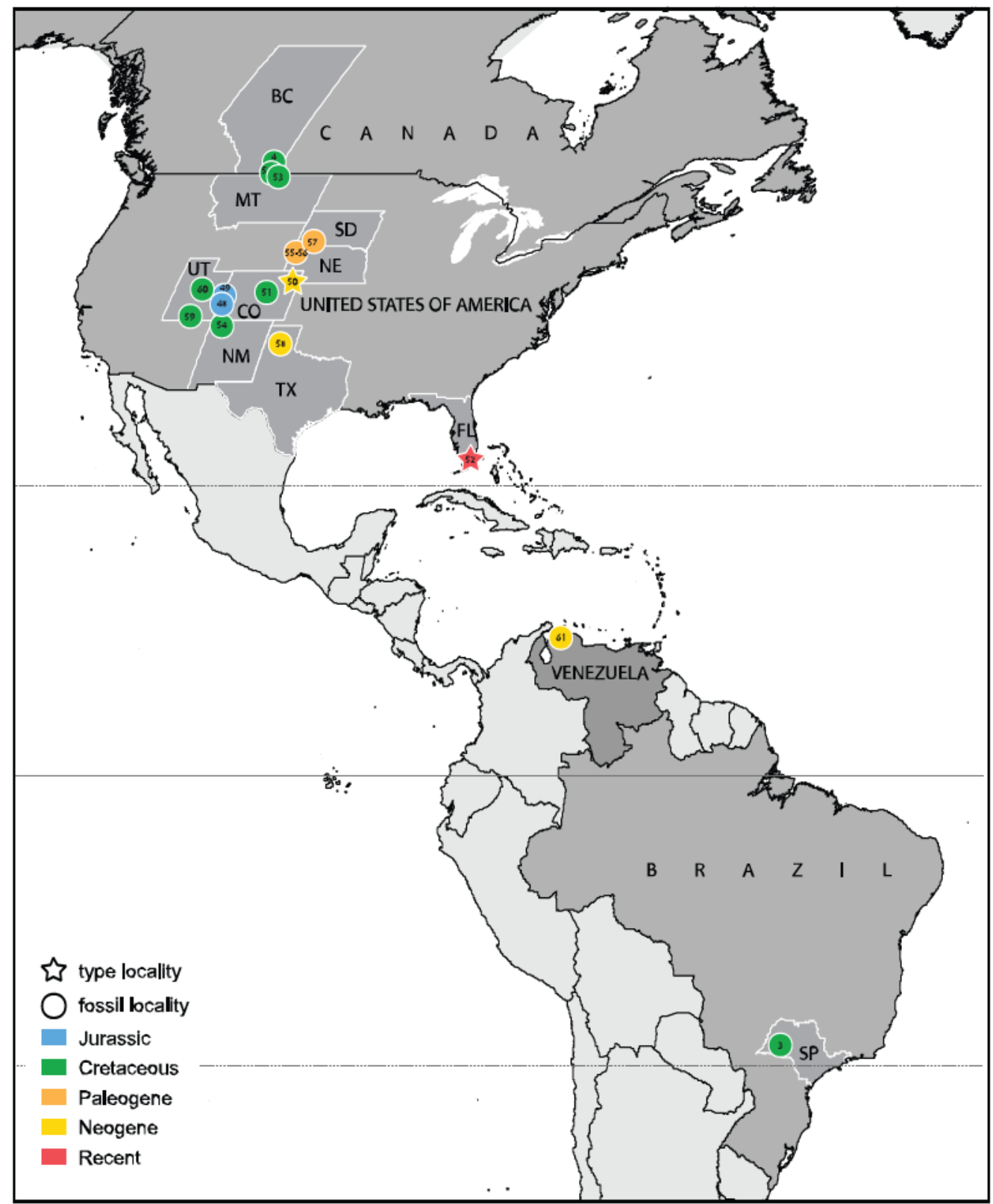

FIGURE 2. The geographic distribution of valid ootaxa in the New World. Type localities are indicated with stars. Locality numbers are cross-listed in Appendix 3. Abbreviations: BC, British Columbia, Canada; CO, Colorado; FL, Florida, MT, Montana; NE, Nebraska; NM, New Mexico; SD, South Dakota; TX, Texas; UT, Utah; SP, São Paulo State, Brazil. Map provided by Walter Joyce.

Testudoflexoolithus bathonicae (Buckman, 1859)

Taxonomic history. Oolithes bathonicae Buckman, 1859 (new oospecies); Testudoflexoolithus bathonicae Hirsch, 1996 (new combination).

Type material. BMNH 37987/HEC 186 (lectotype), "egg A" of Hirsch (1996), an egg embedded in matrix (Van Straelen 1928, fig. 2; Hirsch 1996, fig. 2a-d); BMNH 37987/HEC 186 (paralectotype), "eggs B" of Hirsch (1996), a second egg found in association with the lectotype (Van Straelen 1928, fig. 2; Hirsch 1996, fig. 2a).

Type locality. Hare Bushes-Quarry, great Oolite of Cirencester, England (see Figure 3); White Limestone Formation, Bathonian, Middle Jurassic. 


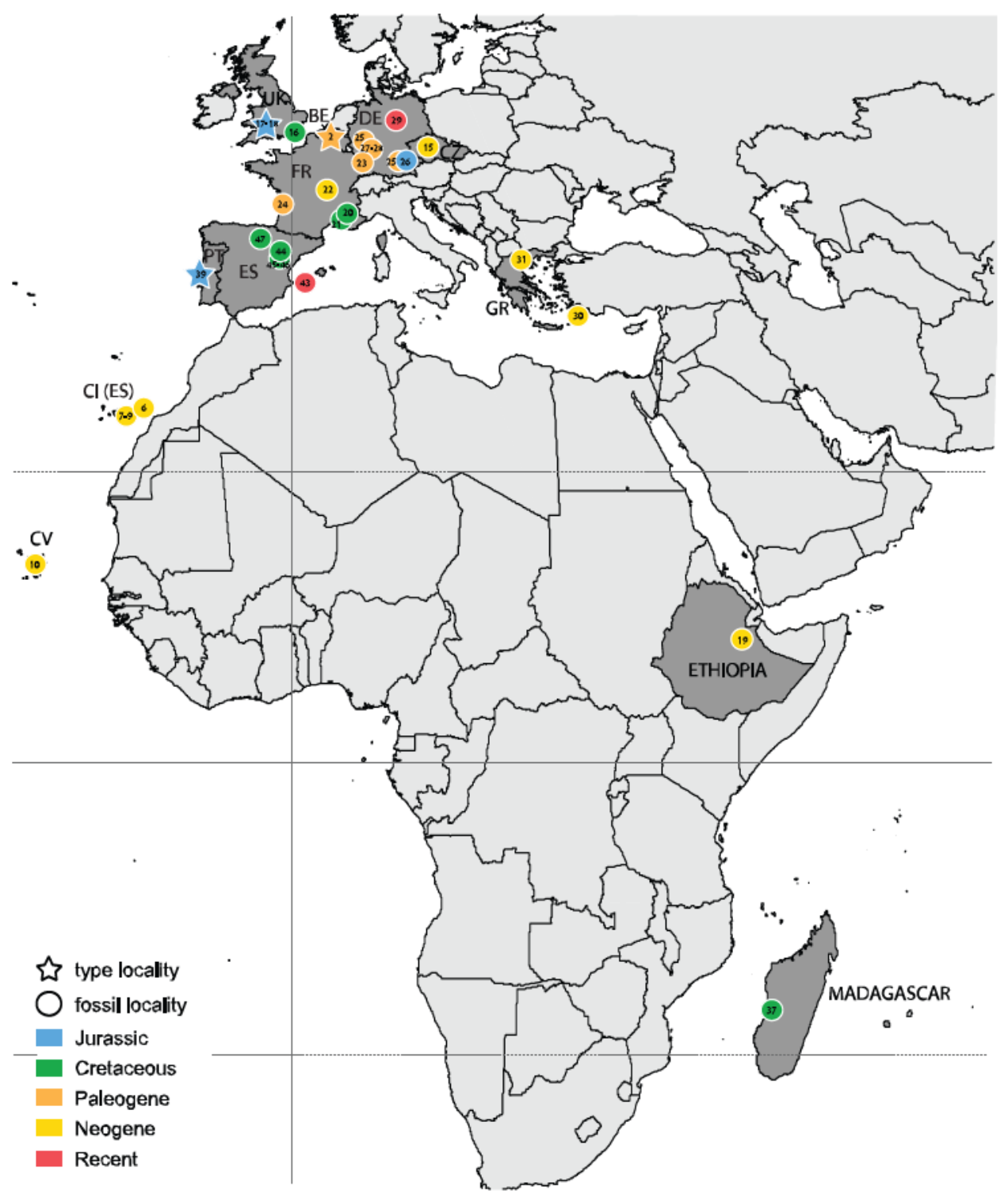

FIGURE 3. The geographic distribution of valid ootaxa in Europe and Africa. Type localities are indicated with stars. Locality numbers are cross-listed in Appendix 3. Abbreviations: BE, Belgium; CI, Canary Islands; CV, Cape Verde; CZ, Czech Republic; DE, Germany; ES, Spain; FR, France; GR, Greece; PT, Portugal; UK, United Kingdom. Map provided by Walter Joyce.

Diagnosis. Eggshell of the ootaxon Testudoflexoolithus bathonicae is diagnosed by small ( $48 \mathrm{~mm}$ by $26 \mathrm{~mm}$ ), ellipsoidal eggs with a shell unit height to width ratio of $1: 1$ and 0.2 to $0.25 \mathrm{~mm}$ thick eggshell. T. bathonicae can be distinguished from $T$. agassizi by a shell thickness that is approximately half as thick.

Comments. Buckman (1859) reports fossil eggs from the Middle Jurassic (Bathonian; Riding et al. 1985) Great Oolite of Cirencester (White Limestone Formation), England, and named them Oolithus bathonicae, which was the first name assigned to a fossil egg. However, Buckman (1859) ruled out a turtle origin for the specimens because they were not spherical. Instead, he suggested that a saurian reptile or perhaps a teleosaurian laid these eggs. It was not until 1996 that Hirsch reexamined these specimens and discovered their true identity, assigning the eggs to a turtle, later confirmed by Cox et al. (1999). Hirsch (1996) furthermore referred O. bathonicae to the newly created taxon Testudoflexoolithus in an attempt to create an internally consistent parataxonomic nomenclatural system for turtle eggs (see "Classification of Fossil Turtle Eggs" above). 
Despite the obvious break with the rules of the ICZN, we maintain the internal integrity of the parataxonomic nomenclature developed by Hirsch (1996), who also designated the lectotype of $T$. bathonicae from the original type series. The microstructure of $T$. bathonicae is similar to recent sea turtle eggs (Hirsch 1996); however, it is unlikely that a chelonioid turtle produced T. bathonicae because this clade did not appear until the Early Cretaceous (Joyce, Parham et al. 2013). Additionally, the ellipsoidal shape of $T$. bathonicae differs from the spherical egg shape of all extant sea turtles.

\section{Testudoolithidae Hirsch, 1996}

Diagnosis. Eggshell of the ootaxon Testudoolithidae is diagnosed by the testudoid basic type, the spherurigidis morphotype, presence of a calcareous layer with interlocking shell units, simple and widely spaced pores between shell units and spheroidal to ellipsoidal egg shape.

\section{Chelonoolithus Kohring, 1998a}

Type and only included oospecies. Chelonoolithus braemi Kohring, 1998a.

\section{Chelonoolithus braemi Kohring, 1998a}

Taxonomic history. Chelonoolithus braemi Kohring, 1998a (new oospecies).

Type material. FUB Guimarota 98-2 (holotype), eggshell (Kohring 1998a, figs. 1-6).

Type locality. Guimarota Coal Mine, Leiria District, Portugal; Alcobaça Formation, Kimmeridgian, Upper Jurassic (Kohring 1998a).

Diagnosis. Eggshell of the ootaxon Chelonoolithus is diagnosed by a shell unit height to width ratio of 1:1, an eggshell thickness of approximately $0.2 \mathrm{~mm}$ and a flat and smooth (unornamented) exterior surface of the eggshell (Kohring 1998a).

Comments. The shell unit height to width ratio is consistent with that of some extant aquatic taxa such as Chelydra serpentina, some Kinosternon spp., some trionychids and Chelodina longicollis (Kohring 1998a). The great age of this specimen, however, makes any attribution to one of these taxa implausible (Joyce, Parham et al. 2013).

\section{Emydoolithus Wang et al., 2013}

Type and only included oospecies. Emydoolithus laiyangensis Wang et al., 2013.

\section{Emydoolithus laiyangensis Wang et al., 2013}

Taxonomic history. Emydoolithus laiyangensis Wang et al., 2013 (new oospecies).

Type material. IVPP V18544 (holotype), a nearly complete egg (Wang et al. 2013, fig. 3a).
Type locality. Jingangkou, Laiyang, Shandong Province, China (see Figure 4); Jingangkou Formation, Upper Cretaceous (Wang et al. 2013).

Diagnosis. Eggshell of the ootaxon Emydoolithus laiyangensis is diagnosed by a symmetrical, elongate, elliptical ( $91 \mathrm{~mm}$ by 22 $\mathrm{mm}$ ) egg; eggshell 0.4 to $0.5 \mathrm{~mm}$ thick; shell unit height to width ratio $2: 1$ to $5: 1 ; 50$ to 60 shell units per square millimeter.

Comments. Emydoolithus laiyangensis is similar to Testudoolithus jiangi in microstructure and eggshell thickness but differs in its elongate egg shape (Wang et al. 2013). Wang et al. (2013) compares E. laiyangensis to the eggs of Podocnemis unifilis but suggests that the eggs belong to an emydid turtle; however, this identification is unlikely considering the lack of emydid fossils from the Cretaceous, combined with the results of recent molecular calibration studies (Joyce, Parham et al. 2013).

\section{Haininchelys Schleich et al., 1988}

Type and only included oospecies. Haininchelys curiosa Schleich et al., 1988.

\section{Haininchelys curiosa Schleich et al., 1988}

Taxonomic history. Haininchelys curiosa Schleich et al., 1988 (new oospecies).

Type material. BSPG uncat. (syntype series), eggshell fragments (Schleich et al. 1988, fig. 4a-h).

Type locality. Hainin, Hainaut Province, Belgium; Upper Paleocene (Schleich et al. 1988).

Diagnosis. Eggshell of the ootaxon Haininchelys curiosa is diagnosed by a shell thickness of about 0.25 to $0.30 \mathrm{~mm}$, a height to width ratio of 1.2:1 to 2.3:1 and primary spherites diameter of 0.02 to $0.04 \mathrm{~mm}$.

Comments. The microstructure of Haininchelys curiosa appears similar to Testudoolithus rigidus; however, the pores are funnel shaped, as opposed to the simple, straight pores of T. rigidus. The external surface of each shell unit is rounded in H. curiosa, similar to the eggshell of Emydura subglobosa, which could indicate that a pleurodire produced this type of egg

\section{Testudoolithus Hirsch, 1996}

Type oospecies. Testudoolithus rigidus Hirsch, 1996.

Diagnosis. Eggshell of the ootaxon Testudoolithus is diagnosed by spheroidal egg shape and an eggshell thickness between 0.2 and $0.8 \mathrm{~mm}$.

\section{Testudoolithus hirschi Kohring, 1999b}

Taxonomic history. Testudoolithus hirschi Kohring, 1999b (new oospecies)

Type material. FUB uncat. eggshell fragments (Kohring 1990c, fig. 1a-f; Kohring 1999b, fig. 62a-c). 


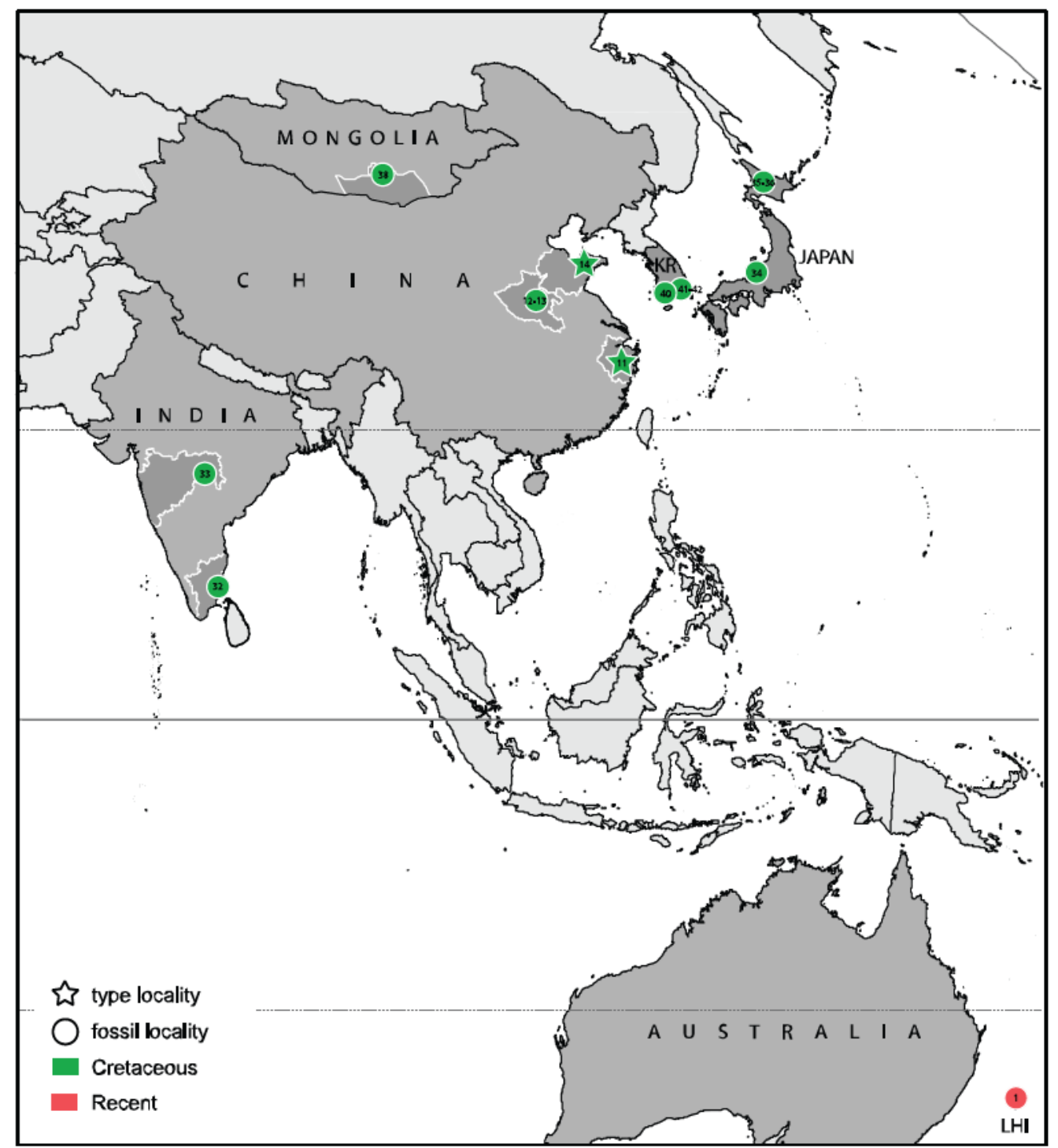

FIGURE 4. The geographic distribution of valid ootaxa in Asia and Australia. Type localities are indicated with stars. Locality numbers are cross-listed in Appendix 3. Abbreviations: KR, Korea; LHI, Lord Howe Island. Map provided by Walter Joyce.

Type locality. KM 11 locality, Guimarota Coal Mine, Leiria District, Portugal; Alcobaça Formation, Kimmeridgian, Upper Jurassic (Kohring 1999b).

Diagnosis. Eggshell of the ootaxon Testudoolithus hirschi is diagnosed by slender shell units with a height to width ratio of 3:1 and a shell thickness of $0.15 \mathrm{~mm}$. T. hirschi can be distinguished from other Testudoolithus ootaxa by the extremely thin eggshell.

Comments. Kohring (1999b) did not assign Testudoolithus hirschi to a turtle taxon. The slender shell units of $T$. hirschi are similar to those of some kinosternid and geoemydid turtles and could indicate that this oospecies was produced by a cryptodire. Note that the locality KM 11 refers to the 11th stratigraphic layer at the Guimarota Coal Mine, which is dominated by limestone and marls (Helmdack 1971).

\section{Testudoolithus jiangi (Fang et al., 2003)}

Taxonomic history. Tiantaioolithus jiangi Fang et al., 2003 (new oospecies); Testudoolithus jiangi Jackson et al., 2008 (new combination).

Type material. ZMNH M8713 (syntype series), a clutch of 23 eggs (Fang et al. 2003, figs. 7-9, pl. 2; Jackson et al. 2008, fig. 2a-c; Jackson et al. 2009, fig. 2). 
Type locality. Shuantang Village, Tiantai County, Zhejiang Province, China; Liangtoutang Formation, Albian, Early Cretaceous (Jackson et al. 2008).

Referred material and range. TM 006, Upper Cretaceous, Chichengshan Formation, Shuangtang, Zhejiang Province, China (Jackson et al. 2008).

Diagnosis. Eggshell of the ootaxon Testudoolithus jiangi is diagnosed by spherical eggs approximately 35 to $52 \mathrm{~mm}$ in diameter, a shell thickness of 0.7 to $1.0 \mathrm{~mm}$ and a shell unit height to width ratio of 2.5:1 to 3:1. T. jiangi can be distinguished from other Testudoolithus ootaxa by an eggshell thickness that is three or more times thicker.

Comments. Fang et al. (2003) erected a new oofamily Testudoolithidae for these specimens, but this taxon had previously already been named by Hirsch (1996). This led Jackson et al. (2008) to propose that Testudoolithidae Fang et al., 2003 is a junior homonym of Testudoolithidae Hirsch, 1996 and that Tiantaioolithus Fang et al., 2003 is a junior subjective synonym of Testudoolithus Hirsch, 1996. The microstructure differs from Testudoolithus hirschi, and therefore, Jackson et al. (2008) proposed a new combination, Testudoolithus jiangi, for the specimens. Jackson et al. (2008) compared Testudoolithus jiangi with extant tortoise eggs but did not suggest that a tortoise produced these eggs because of their Cretaceous age. It is likely that the similarity between Testudoolithus jiangi and some extant tortoises is due to similar ecology (Jackson et al. 2008).

\section{Testudoolithus rigidus Hirsch, 1996}

Taxonomic history. Testudoolithus rigidus Hirsch, 1996 (new oospecies).

Type material. UCM 55806/HEC 425 (holotype), half of an egg with well-preserved eggshell (Hirsch 1996, fig. 1a-c).

Type locality. UCM L 87086, North of Stoneham, Weld County, Colorado, USA; Ogallala Formation, Miocene (Hirsch 1996).

Referred material and range. BMNH 47208, Lower Cretaceous, Gault Formation, Folkstone, England (Hirsch 1983); CMNH AL 108, Pliocene, Sidi Hakoma Member of the Hadar Formation, Hominid Site, Afar, Ethiopia (Hirsch 1983); MLP uncat., Pliocene, Calcarenites, Gran Canaria (Hirsch and López-Jurado 1987); MNHN-Mr. Pascal 1871-222, Miocene, Saint-Gérandle-Puy, Department of Allier, France (Kohring 1993).

Diagnosis. Eggshell of the ootaxon Testudoolithus rigidus is diagnosed by shell unit height to width ratio of about $2: 1$, eggshell thickness 0.22 to $0.24 \mathrm{~mm}$ and spheroidal eggs ( $42 \mathrm{~mm}$ by $47 \mathrm{~mm}$ ). T. rigidus is distinguished from $T$. hirschi by a smaller height to width ratio and differs from $T$. jiangi by eggshell that is a third the thickness.

Comments. Van Straelen (1928) described a fossil turtle egg from the late Early Cretaceous (Albian; Gale et al. 1996) of England, and Hirsch (1983) confirmed this identification. Later, this specimen was assigned to the oospecies Testudoolithus rigidus Hirsch, 1996. Hirsch (1996) compared the microstructure of $T$. rigidus with that of the extant taxa Gopherus polyphemus and Chelonoidis carbonaria and determined that $T$. rigidus is more similar to G. polyphemus and that the eggshell thickness is thinner than C. carbonaria. Mueller-Töwe et al. (2011) describe five turtle eggs and multiple eggshell fragments from the Pliocene Apolakkia Formation of Rhodes, Greece. Despite some diagenetic alteration, the eggshell microstructure allowed assignment to the oospecies T. rigidus. Mueller-Töwe et al. (2011) suggest that the eggs were laid by a giant land tortoise.

\section{Invalid and Problematic Ootaxa}

\section{Emydidarum ovum Schleich and Kästle, 1988 nomen nudum}

Material. BSPG 1952 II, 270 isolated eggs and eggshell fragments (Schleich and Kästle 1988, pl. 42.1-8)

Locality Gaimersheim, Germany; Chattium, Upper Oligocene (Schleich and Kästle 1988).

Comments. Schleich and Kästle (1988) proposed a classification system and zoological nomenclature for fossil eggshell of geckos, lizards, snakes, crocodilians, turtles and tortoises. However, their system and nomenclature were never widely accepted. Schleich and Kästle (1988) suggested Emydidarum ovum as the name for fossil turtle eggs (presumably for emydid eggs) that were difficult to systematically classify. A formal diagnosis and type specimen, however, were never published, and $E$. ovum is therefore herein interpreted as a nomen nudum.

\section{Testudinarum ovum Schleich and Kästle, 1988 nomen nudum}

Material. Eggshell fragments (Schleich and Kästle 1988, pl. 44.3-8, pl. 45.1-8; Schleich et al. 1988, figs. 2-3).

Locality. Pöttmes and Weidorf, Bavaria, Germany; Aragonium, Middle Miocene (Schleich and Kästle 1988).

Comments. See previous comments for Emydidarum ovum Schleich and Kästle, 1988. Schleich and Kästle (1988) suggested the name Testudinarum ovum for fossil turtle eggs that were difficult to systematically classify. A formal diagnosis and type specimen were never published, however, and T. ovum is therefore interpreted herein as a nomen nudum. Interestingly, one of these specimens shows purported evidence of a cuticle layer on the exterior eggshell surface (Schleich and Kästle 1988), a feature typical of some avian eggshell.

\section{Testudoolithus magnirigidus Zelenitsky, 1995 nomen nudum}

Material. TMP 94.16.1A, eggshell fragments (Zelenitsky 1995, pl. 8.1-6, pl. 9.1-6, pl. 10.1-2).

Locality. Wann's Hill Locality, southern Alberta, Canada; Oldman Formation, Campanian, Late Cretaceous (Zelenitsky 1995, fig. 2.1). 
Comments. The in situ clutch described by Zelenitsky et al. (2008) and McGee (2012) were referred to the name Testudoolithus magnirigidus. Eggshell of this oospecies is thicker than $T$. rigidus but comparable in eggshell thickness to $T$. jiangi. However, the shell unit comprising T. magnirigidus displays a domed external surface and "lateral feathering" (Zelenitsky et al. 2008), both of which are absent in T. jiangi (McGee 2012). Zelenitsky et al. (2008) compared the structure of the eggs from the in situ clutch with eggs discovered inside gravid Adocus specimens from Alberta and Utah. They concluded that T. magnirigidus can be confidently identified as the eggs of an Adocus species.

Zelenitsky (1995) named the taxon Testudoolithus magnirigidus in her unpublished master's thesis. According to Article 8.1.3 of the fourth edition of the ICZN, species names are only valid if "produced in an edition containing simultaneously obtainable copies by a method that assures many identical and durable copies." An unpublished master's thesis does not meet these criteria because it is not widely distributed, and therefore, T. magnirigidus is not a valid taxon according to the ICZN. We believe that T. magnirigidus should be formally described and thereby made available. Such validation is important because a high level of homoplasy in turtle eggs (as was documented above in the "Cladistic Analysis of Eggs and Eggshell Characters" section) suggests that several different turtle taxa could produce eggs with similar microstructure as T. magnirigidus. Therefore, specimens that are not associated with embryos or gravid females might be incorrectly interpreted as Adocus eggs. Additionally, validation would facilitate future comparisons with new specimens.

\section{Acknowledgments}

We thank D. Barta, J. Simon and A. Martin for insightful discussion and helpful comments on early versions of the manuscript, and R. Jackson for help with translations. Additionally, we thank the Montana State University Interlibrary Loan staff for help finding many of the obscure references used in this survey. We thank W. Joyce for inviting us to write this review and for help with the construction of the figures, M. Knell, M. Moreno-Azanza and A. Sellés for reviewing the manuscript. L. Gall and W. Joyce edited the manuscript; whereas M. Delfino, J. Sterli, P. Romano and V. Volpato checked foreign language citations for spelling mistakes. Partial support was provided by National Science Foundation Grant No. 0847777 to D. Varricchio.

\section{Received 14 January 2014; revised and accepted 28} July 2014.

\section{Appendix 1: Institutional Abbreviations}

BMNH The Natural History Museum, London, United Kingdom
BSPG Bayerische Staatssammlung für Paläontologie and Geologie, Munich, Germany

$\mathrm{CMNH}$ Cleveland Museum of Natural History, Cleveland, Ohio, USA

FUB Institut für Paläontologie, Freie Universität Berlin, Berlin, Germany

HEC Hirsch Eggshell Catalogue, University of Colorado, Boulder, Colorado, USA

IVPP Institute of Vertebrate Paleontology and Paleoanthropology, Beijing, China

MCZ Museum of Comparative Zoology, Cambridge, Massachusetts, USA

MLP Museum Las Palmas, Gran Canaria, Canary Islands

MNHN Muséum National d'Histoire Naturelle, Laboratoire de Paléontologie, Paris, France

TM Tiantai Prefecture Museum, Tiantai, Zhejiang Province, China

TMP Royal Tyrrell Museum of Palaeontology, Alberta, Canada

UCM University of Colorado Museum, Boulder, Colorado, USA

ZMNH Zhejiang Museum of Natural History, Hangzhou, Zhejiang Province, China

\section{Appendix 2: Named Turtle Oogenera}

Chelonoolithus Kohring, 1998a (type oospecies: Chelonoolithus braemi Kohring, 1998a)

Emydidarum Schleich and Kästle, 1988

(type oospecies: Emydidarum ovum Schleich and Kästle, 1988)

Emydoolithus Wang et al., 2013

(type oospecies: Emydoolithus laiyangensis Wang et al., 2013)

Haininchelys Schleich et al., 1988

(type oospecies: Haininchelys curiosa Schleich et al., 1988)

Oolithes Buckman, 1859

(type oospecies: Oolithes bathonicae Buckman, 1859)

Testudinarum Schleich and Kästle, 1988

(type oospecies: Testudinarum ovum Schleich and Kästle, 1988)

Testudinidovum Schleich and Kästle, 1988 (nomen nudum, lacking diagnosis and type species)

Testudinovum Schleich and Kästle, 1988 (nomen nudum, lacking diagnosis and type species)

Testudoflexoolithus Hirsch, 1996

(type oospecies: Testudoflexoolithus bathonicae

[Buckman, 1859])

Testudoolithus Hirsch, 1996

(type oospecies: Testudoolithus rigidus Hirsch, 1996) 
Tiantaioolithus Fang et al., 2003

(type oospecies: Tiantaioolithus jiangi Fang et al., 2003)

\section{Appendix 3: Biogeographical Summary of Fossil Turtle Eggs, Embryos, Nests and Copulating Pairs}

Numbers in brackets reference Figures 2, 3 and 4 .

\section{Australia}

[1] Pleistocene; Ned's Beach Formation; Lord Howe Island; Meiolania platyceps; eggs and clutches (Anderson 1925; Gaffney 1996)

Comments. Numerous eggs and clutches associated with bones of Meiolania platyceps occur in the Pleistocene Ned's Beach Formation of Lord Howe Island, Australia, and have been assigned to this taxon (Anderson 1925; Gaffney 1996). This taxonomic assignment seems plausible because the eggs are quite large, approximately $9 \mathrm{~cm}$ in diameter (Gaffney 1996). It is also plausible that various sea turtles (Chelonioidea) laid their eggs at some of these localities, but no extant chelonioid turtle is known to lay eggs of this size (Ernst and Barbour 1989). M. platyceps otherwise represents the only taxon known from Lord Howe Island that was capable of laying eggs of this size. However, these eggs remain undescribed and lack embryonic remains, and therefore, this identification remains tentative for the moment.

\section{Belgium}

[2] Late Paleocene; Hainaut Province; Haininchelys curiosa; eggs (Schleich et al. 1988)

\section{Brazil}

[3] Late Cretaceous (Turonian-Santonian); Adamantina Formation; São Paulo State; ?Podocnemis; egg with a possible embryo (Azevedo et al. 2000)

Comments. Azevedo et al. (2000) describe a possible turtle egg and embryo from the Late Cretaceous (Turonian-Santonian) Adamantina Formation of Brazil (Nava and Martinelli 2011). Additionally, the authors tentatively assign the egg to the genus Podocnemis. However, the study only included examination of structural features of the outer egg surface and low quality computed tomography scans for embryo identification. Confirmation of their results requires identification of the aragonite eggshell composition and mechanical preparation or use of synchrotron tomography for detailed description of the embryo. It is unlikely that future analysis will confirm the taxonomic attribution of this material to crown group Podocnemis because this clade did not diversify until the Tertiary. However, it is plausible that this egg is attributable to the clade Podocnemididae as this taxon is known to have Cretaceous representatives (Gaffney et al. 2011).

\section{Canada}

[4] Late Cretaceous, late Campanian; Dinosaur Park Formation; Alberta; Basilemys variolosa and Testudoolithus magnirigidus/Adocus sp.; gravid turtles (Zelenitsky et al. 2008; Braman and Brinkman 2009)
[5] Late Cretaceous, late Campanian; Oldman Formation; Alberta; Testudoolithus magnirigidus/Adocus sp.; clutch of eggs with embryos (Zelenitsky 1995; Zelenitsky et al. 2008; McGee 2012)

Comments. McGee (2012) provides a detailed description of the morphology of the embryonic remains from a clutch of turthe eggs from the late Campanian Oldman Formation of Alberta using computer tomography. She concurs with Zelenitsky et al.'s (2008) referral to Adocus sp. and also concludes that the embryos died at a late stage of development. Additionally, an undescribed specimen of Basilemys variolos $a$ from the Upper Cretaceous (late Campanian) Dinosaur Park Formation on display at the Royal Ontario Museum was discovered to contain eggs when the carapace was accidently broken (Braman and Brinkman 2009).

\section{Canary Islands}

[6] Miocene and Pliocene; Calcarenites; ?Geochelone burchardi; Fuerteventura; eggs (Rothe and Klemmer 1991)

[7] Pliocene; Calcarenites; Testudoolithus rigidus/? Geochelone; Gran Canaria; egg (Macau-Vilar 1958; López-Jurado 1985; Hirsch and López-Jurado 1987). Note: Specimen was subsequently lost.

[8] Tertiary; Calcarenites; ?Geochelone; Lanzarote and Fuerteventura; eggs (Hutterer et al. 1997)

[9] Miocene; Calcarenites; Lanzarote; eggs (GarcíaTalavera 1990)

Comments. Fossil turtle eggs have been reported from Miocene and Pliocene deposits from Fuerteventura, Lanzarote and Gran Canaria, Canary Islands. All of these eggs were assigned to the genus Geochelone because of their similarity to eggs of modern Geochelone species (Hutterer et al. 1997). However, the eggs from Fuerteventura were most likely laid by G. burchardi, the only species of testudinid turtle, fossil or modern, known from this island (Rothe and Klemmer 1991).

\section{Cape Verde}

[10] Miocene; Maio; eggs (Bebiano 1932)

Comments. Bebiano (1932) reports eight turtle eggs from the Miocene of the Republic of Cape Verde. However, this identification was made using the egg shape and the fact that they were found in embedded in calcareous sands. Further investigation is needed to confirm this identification.

\section{China}

[11] Early Cretaceous, Albian and Late Cretaceous, Cenomanian-Turonian; Liangtoutang and Chichengshan formations, respectively; Zhejiang Province; Testudoolithus jiangi; egg and clutch (Fang et al. 2003; Jackson et al. 2008; Jin 2009)

[12] Late Cretaceous; Nanchao Formation; ?emydid; eggs with embryos (Cohen et al. 1995)

[13] Cretaceous; Henan Province; egg with embryo (Fang et al. 2009)

[14] Late Cretaceous; Jingangkou Formation; Shandong Province; Emydoolithus laiyangensis; egg (Wang et al. 2013) 
Comments. Yabe and Ozaki (1929) describe purported fossil turtle eggs from the Cretaceous Tsuantou Formation (Zhang 2009) of Liaoning Province, China. This identification was based on the spheroidal egg shape rather than microstructural features of the eggshell. Wang et al. (2013) recently identified these specimens as those of dinosaurs but did not assign them to a specific oospecies.

Turtle eggs with embryos are also known from the Upper Cretaceous Nanchao Formation of China. These specimens are hypothesized to belong to an emydid turtle; however, Cohen et al. (1995) failed to provide a formal description of this material. If this identification proves correct, this specimen would push the fossil record of emydid turtles back 40 million years (Cohen et al. 1995), which seems unlikely considering recent molecular calibration studies (Joyce, Parham et al. 2013). Additionally, a turtle egg with a purported embryo was discovered in Xixia County, Henan Province, China (Fang et al. 2009, fig. 1).

\section{Czech Republic}

[15] Early Miocene; Testudoolithus; eggshell (Kohring 1998b, 1999a)

Comments. Kohring (1998b, 1999a) reports Testudoolithus eggshell from the Early Miocene of the Czech Republic. One of these specimens exhibits pathological multilayered eggshell.

\section{England}

[16] Early Cretaceous, Albian; Gault Formation; Kent; Testudoolithus rigidus; egg (Van Straelen 1928; Hirsch 1983, 1996)

[17] Middle Jurassic, Bathonian; White Limestone Formation; Gloucenstershire; Testudoflexoolithus bathonicae; eggs (Buckman 1859; Hirsch 1996; Cox et al. 1999)

[18] Middle Jurassic, Bathonian; White Limestone Formation; Gloucenstershire; eggs (Carruthers 1871)

Comments. In addition to the specimens described by Buckman (1859), Carruthers (1871) also describes fossil eggs from the Great Oolite and agrees with Buckman that the eggs were reptilian but suggests that turtles or pterosaurs laid these eggs. He named two new ootaxa, Oolithus sphaericus for specimens from Stonesfield, England, and O. obtusatus for a single egg from the Isle of Wight. However, Carpenter and Alf (1994) suggest that $O$. sphaericus specimens are actually dinosaur eggs, and Mikhailov et al. (1996) categorized O. sphaericus and O. obtusatus as incertae sedis. Further study of these specimens is required to determine their true taxonomic identity. Ensom (1997) describes numerous eggshell fragments and discusses their similarity to turtle eggshell described by Kohring (1990a) but ultimately rejects this identification in favor of megaloolithid eggshell, typically assigned to sauropod dinosaurs (Ensom 2002).

\section{Ethiopia}

[19] Pliocene; Hadar Formation; Afar; Testudoolithus rigidus; eggs (Hirsch 1983)

Comments. Hirsch (1983) discusses two partially and one completely altered turtle eggshell from the Pliocene Hadar Formation (Hominid Site) in the Afar region of Ethiopia. He determines that although aragonite might be completely replaced by calcite, the eggshell can be confidently identified as that of a turtle using polarized light and scanning electron microscopy (Hirsch 1983), presumably because specimens preserve a pseudomorph of the original aragonite structure.

\section{France}

[20] Early Cretaceous, late Albian; ?Formation of Salazac; Department of Gard; egg (Masse 1989)

[21] Late Cretaceous; Testudoolithidae; Department of Bouches-du-Rhône; eggshell (Garcia 2000)

[22] Early Miocene; Department of Allier; Testudoolithus rigidus/?Cheirogaster sp.; eggs (Kohring 1993)

[23] Eocene; Department of Bas-Rhin; eggs (Kuntz 1981)

[24] Tertiary; Department of Lot-et-Garonne; eggs (Brunet 1838)

Comments. Masse (1989) discusses one complete and one partial pliable turtle egg from the Early Cretaceous (late Albian) of France. These specimens are diagenetically altered, but the radiating crystals suggest that they were originally composed of aragonite. Garcia (2000) also describes several eggshell fragments from the Late Cretaceous of France and assigns the specimens to Testudoolithidae. Kohring (1993) reports six turtle eggs from the Early Miocene of France and assigns them to Cheirogaster sp. This identification is based on size and shape of the eggs and not microstructural features. Kuntz (1981) mentions six oval and smooth turtle eggs from the Eocene of France. Brunet (1838) reports three turtle eggs measuring approximately $6.0 \mathrm{~cm}$ by $2.5 \mathrm{~cm}$ from the Tertiary of the Gironde basin.

\section{Germany}

[25] Oligocene and Miocene; Testudinarum ovum; State of Bavaria; eggs (Schleich and Kästle 1988)

[26] Jurassic; Solnhofen; State of Bavaria; ?Eurysternid; gravid turtle (Joyce and Zelenitsky 2002)

[27] Eocene; Messel; State of Hesse; Allaeochelys crossesculpta; copulating pair (Joyce et al. 2012)

[28] Tertiary; Trionyx gergensi or Chelonia mydas; State of Rhineland-Palantinate; egg (Gergens 1860; Meyer 1860; Hummel 1929)

[29] Pleistocene; State of Saxony-Anhalt; ?Emys orbicularis; eggs and embryo (Hemprich 1932)

Comments. Joyce and Zelenitsky (2002) describe a gravid eurysternid turtle from a Late Jurassic limestone concretion discovered near the village of Schamhaupten, Germany. After initial preparation, the concretion was cut into four sections to determine whether it was fossiliferous, revealing four circular egglike objects within a turtle shell. However, investigation of the microstructure revealed complete diagenetic alteration of the eggshell. Further, the eggshell now seems to be inside out (e.g., the base of the shell units are on the exterior of the eggshell), and the exact mechanism for such preservation remains unknown. The authors conclude that these eggs must be referred to as pseudomorphs because no details of the eggshell microstructure can be ascertained (Joyce and Zelenitsky 2002). Hemprich (1932) discusses turtle eggs (one containing a possible embryo) from the Pleistocene of Germany and assigns them to Emys orbicularis; however, this assignment seems to be based 
on their similarity to the eggs of this extant species and not eggshell microstructure or embryonic remains. Therefore, a detailed systematic description of these specimens is needed. Meyer (1860) mentions turtle eggs from the Tertiary of Mainz, Germany, and suggests that they belong to Trionyx gergensi, based on egg size and shape. In contrast, Gergens (1860) suggests that these eggs belong to Chelonia mydas. Later, Hummel (1929) mentions the same specimens and agrees with Meyer (1860) that they were laid by Trionyx gergensi; however, the author does not give his reasoning for this assignment.

Preservation of paired turtle specimens includes numerous examples of Allaeochelys crassesculpta are known from the Eocene Messel Pit in Germany. However, Joyce et al. (2012) provide the first definitive evidence that these turtles died while copulating. The authors inferred the gender of the individuals by using body size and tail length (i.e., males are smaller, have longer tails and lack plastral kinesis). Additional confirmation that these turtles died in the act of mating includes their in-line position and the presence of interlocking tails in some specimens (Joyce et al. 2012). The authors hypothesize that once the male mounted the female, they sank to the bottom of the lake where anoxic conditions resulted in their demise. This is further supported by the fact that some extant aquatic turtles "freeze" while mating and sink to the bottom of open bodies of water (Joyce et al. 2012).

\section{Greece}

[30] Pliocene; Apolakkia Formation; Rhodes; Testudolithus rigidus/?Giant land tortoises; eggs (MuellerTöwe et al. 2011)

[31] Late Miocene; central Macedonia; eggs (Del Campana 1919)

Comments. Del Campana (1919) describes six fossil turtle eggs from the Upper Miocene of Thessaloniki (formerly Salonica), Greece, and suggests that these eggs are those of a sea turtle because they occurred in marine sediments. However, microstructural analysis of the eggshell was not done.

\section{India}

[32] Late Cretaceous; State of Tamil Nadu; egg (Sahni 1957)

[33] Late Cretaceous, Maastrichtian; Lameta Formation; State of Maharashtra; ?Pelomedusid; eggshell and partial clutch (Mohabey 1998)

Comments. Sahni (1957) reports the first fossil egg from India. This elongate egg measures $49 \mathrm{~mm}$ wide by $27 \mathrm{~mm}$ long; however, this identification is based on gross morphology and not microstructural features. Further research is necessary to confirm its turtle affinities. Mohabey (1998) reports a partial turtle nest and eggshells from the Lower Cretaceous (Maastrichtian) Lamenta Formation of India and mentions turtle eggs from the Pleistocene of the Narmada Valley. However, Kohring (1999b) questions the turtle origin of the Cretaceous specimens because of the calcite mineralogy and poor quality of the photographs. Additionally, Mohabey (1998) identified a mammillary layer at the basalmost portion of the eggshell. This feature is characteristic of avian and nonavian theropods; therefore, assignment of these specimens to a turtle remains questionable (Jackson et al. 2008; Knell et al. 2011), and further analysis is needed.

\section{Japan}

[34] Early Cretaceous; Kuwajima Formation; Ishikawa

Prefecture; eggshell (Isaji et al. 2006)

[35] Late Cretaceous (Coniacian); Middle and Upper Yezo Group; Hokkaido; ?Protostegid; egg (Fukuda and Obata 1991)

[36] Late Cretaceous (Coniacian); Hokkaido; ?Chelonia and ?'Trionychid; eggs (Obata et al. 1972)

Comments. Isaji et al. (2006) describe turtle eggshells from the Lower Cretaceous Kuwajima Formation of central Japan and suggest that these specimens were laid by an unidentified aquatic turtle. Fukuda and Obata (1991) and Obata et al. (1972) report on turtle eggs from the Late Cretaceous (TuronianConiacian) of Hokkaido, Japan. Both specimens preserved two superimposed layers that are thought to represent secondary diagenetic deposits. Additionally, the specimens described by Isaji et al. (2006) also seem to be diagenetically altered because aragonite was not found after staining the thin sections; however, the turtle origin of these specimens is supported by the radiating crystallite in the shell units.

\section{Madagascar \\ [37] Late Cretaceous (Campanian); Menabe Region; eggs (Lawver 2013)}

Comments. Lawver (2013) describes three associated spherical eggs from the Late Cretaceous (Campanian) Morondava basin, western Madagascar, and assigns them to Testudoolithus oosp. Two of the eggs lack evidence of eggshell in hand sample, and their spherical morphology results from infilling of the eggs by sediment prior to erosion of the eggshell. The third egg preserves eggshell on approximately half of the specimen. Thin sections of the eggshell reveal substantial diagenetic alteration of the original aragonite. However, portions of the lower twothirds of the eggshell preserve the original crystalline structure, thus allowing definitive assignment to Testudines (Lawver 2013). Bright red to orange-red color under cathodoluminescence suggests replacement of the original aragonite by calcite (Lawver 2013).

\section{Mongolia}

[38] Late Cretaceous; Ömnögovi Province; egg with embryo (Mikhailov et al. 1994)

Comments. Ologoy-Ulan-Tsav locality of Mongolia. These specimens, important because at least one egg contains embryonic remains, require further research.

\section{Portugal}

[39] Late Jurassic, early Kimmeridgian; Alcobaça Formation; Leiria District; Testudoolithus hirschi and Chelonoolithus braemi; egg and eggshell (Kohring 1990b, 1990c, 1998a, 1999a, 2000)

Comments. Kohring (1990c) reports two different types of turtle eggshell from the Upper Jurassic (early Kimmeridgian) Guimarota mine of Portugal. The author suggests that the specimens belong to cryptodiran turtles because only these turtles are known from the Guimarota mine. 


\section{South Korea}

[40] Late Cretaceous, Campanian; Seonso Formation; South Jeolla Province; eggs (Huh and Zelenitsky 2002; Lee 2003)

[41] Early Cretaceous, Albian; Jindong Formation; South Gyeongsang Pronvince; eggs (Lee 2003)

[42] Late Cretaceous; Goseong Formation; South Gyeongsang Pronvince; eggs (Yang et al. 2006; Paik et al. 2012)

Comments. Huh and Zelenitsky (2002) report fossil eggs from the Upper Cretaceous (Campanian; Kim et al. 2008) Seonso Formation of South Korea and tentatively identify a partial egg and eggshell fragments as those of a turtle. This identification is based on the small size, eggshell thickness and smooth outer surface; however, no microstructural features are preserved because the eggshell is completely altered to sparry calcite. Lee (2003) provides limited locality data for these specimens, as well as for undescribed fossil turtle eggs from the late Early Cretaceous (Albian) Jindong Formation of South Korea.

\section{Spain}

[43] Pleistocene; Testudoolithus; Formentera; eggs (Filella-Subirà et al. 1999)

[44] Early Cretaceous, early Barremian; El Castellar Formation; Teruel Pronvince; Testudoolithus, Testudoflexoolithus/?Batagurinae, Testudoid and others; eggshell (Kohring 1990a; Ruiz-Omeñaca et al. 2004)

[45] Early Cretaceous, late Barremian; Cuenca Province; Testudoolithus; eggshell (Buscalioni et al. 2008)

[46] Early Cretaceous, Valanginian-Hauterivian; Villanueva de Huerva Formation; Aragon; Testudoolithidae; eggshell (Moreno-Azanza et al. 2008, 2009)

[47] Early Cretaceous, late Berriasian; Leza Formation; La Rioja Province; Testudoolithidae; eggshell (Moreno-Azanza, Gasca et al. 2013)

Comments. Kohring (1990a) describes three types of eggshell fragments from the Early Cretaceous (lower Barremian) of Galve, Spain. His type A eggshell was attributed to a semiaquatic turtle because its shell unit height to width ratio is 1:1 (Kohring 1990a). The type B eggshell exhibits very large pores that are surrounded by smaller pores, which could be an artifact of diagenesis. Kohring (1990a) suggests that this eggshell type belongs to a batagurid turtle. Type $\mathrm{C}$ eggshell was assigned to tortoises because of similar eggshell microstructure (Kohring 1990a).

Filella-Subirà et al. (1999) describe a partial clutch of six Testudoolithus eggs from the Pleistocene of the Balearic Islands and attributed them to a large tortoise. They calculated that the nest chamber measured $13.5 \mathrm{~cm}$ long by $14.5 \mathrm{~cm}$ wide and 11 $\mathrm{cm}$ high and occurred between 25 and $27 \mathrm{~cm}$ deep. They suggest a maximum length of $78.9 \mathrm{~cm}$ for the adult female (FilellaSubirà et al. 1999). Buscalioni et al. (2008) briefly describe turtle eggshell fragments from the Early Cretaceous (Upper Barremian) of Spain, which can likely be assigned to Testudoolithus based on the aragonite crystalline structure in their fig. 10a.

Moreno-Azanza et al. (2008) describe eggshell fragments from the Early Cretaceous (Valanginian-Hauterivian) of Spain and assign the specimens to Testudoolithidae indet. They suggest that a testudinid turtle laid the eggs; however, tortoises did not appear until after the Mesozoic. Moreno-Azanza et al. (2009) also suggests that these turtle eggshells could represent a new Testudoolithus oospecies. Moreno-Azanza, Gasca et al. (2013) identify eggshell fragments from the Early Cretaceous (upper Berriasian) of northern Spain as Testudoolithidae and suggest that these specimens could belong to a new oospecies.

\section{United States of America}

[48] Late Jurassic, Tithonian; Morrison Formation; Colorado; egg (Bray and Hirsch 1998)

[49] Late Jurassic, Tithonian; Morrison Formation; Colorado; egg (Hirsch et al. 1987)

[50] Oligocene-Miocene; Ogallala Formation; Colorado; Testudoolithus rigidus/?Stylemys; egg (Hirsch and Bray 1988; Hirsch 1996)

[51] Late Cretaceous, Maastrichtian; Fox Hills Formation; Colorado; sea turtle; nest (Bishop et al. 2011)

Comments. Turtle eggshells (Hirsch and Packard 1987; Hirsch et al. 1987) and possible pliable or soft-shelled eggs (Bray and Hirsch 1998) are reported from the Jurassic (late Kimmeridgian-Tithonian; Kowallis et al. 1991) Bushy Basin Member of the Morrison Formation of Colorado; however, this assignment requires additional research. Hirsch and Bray (1988) describe spherical eggs from the Oligocene-Miocene Ogallala Formation of Colorado and discuss how spheroidal owl eggs could be confused with those of some turtles. They determined that avian and turtle eggs cannot be distinguished by macrostructure alone. Further, they identify three of the four eggs as avian, based on their eggshell microstructure, but one might belong to a turtle (Bray and Hirsch 1998).

[52] Pleistocene; Florida Oolite; Florida; Testudooflexoolithus agassizi; egg (Hirsch 1996)

Comments. Agassiz discovered flexible turtle eggshell fragments in the Pleistocene Florida Oolite in the 1800s (Hirsch 1996), but they remained undescribed until 1996.

[53] Late Cretaceous, Campanian; Judith River Formation; Montana; eggs with embryos (Clouse 2001; Jackson and Schmitt 2008)

Comments. Clouse (2001) reports a weathered clutch of fossil turtle eggs from the Upper Cretaceous (Campanian) Judith River Formation of Montana. This clutch consists of at least 13 eggs, some of which contain embryonic bones. Jackson and Schmitt (2008) briefly described the eggshell microstructure and demonstrated that the clutch contained at least 1 pathological, multilayered egg.

[54] Late Cretaceous, Campanian; Fruitland Formation; New Mexico; Testudoolithus sp.; eggshell (Tanaka et al. 2011)

Comments. Tanaka et al. (2011) describe numerous isolated turtle eggshell fragments from the Upper Cretaceous (Campanian) Fruitland Formation of New Mexico. They identified the specimens as Testudoolithus oosp.

[55] Oligocene; Brule Formation; Nebraska; eggs (Hirsch 1983) 
[56] Oligocene; White River Group; Nebraska; ?Stylemys nebrascensis; eggs (Hay 1908). Note: Specimens were subsequently lost.

[57] Oligocene; Nebraska and South Dakota; eggs (Hirsch and Packard 1987)

Comments. Hirsch (1983) describes at least four altered turtle eggs from the Oligocene Brule Formation of Nebraska. X-ray diffraction analysis shows complete replacement of aragonite by calcite; however, polarized light microscopy reveals the original crystal morphology. Hay (1908) mentions several turtle eggs from the Oligocene White River Group of Nebraska that he identifies as Stylemys nebrascensis because this taxon is commonly found in these deposits and few other species are known. This identification remains questionable because the specimens have since been lost (Hirsch 1996). Additionally, Hirsch and Packard (1987) examined numerous spherical eggs from Nebraska and South Dakota and identified all but two as turtle eggs. The latter they identified as avian, most likely those of owls (Hirsch and Packard 1987).

\section{[58] Late Pliocene; Texas; egg (Brattstrom 1961)}

Comments. Brattstrom (1961) briefly mentions a fossil egg associated with skeletal elements from a tortoise in the Late Pliocene of Texas. This specimen measures 49.5 by 48.2 by $46.9 \mathrm{~mm}$ in size but has not been systematically described.

[59] Late Cretaceous, Campanian; Kaiparowits Formation; Utah; Adocus sp.; gravid turtle (Knell et al. 2011)

[60] Late Cretaceous; Maastrichtian; North Horn Formation; Utah; eggshell (Difley 2007)

Comments. Knell et al. (2011) describe a gravid specimen of Adocus from the Upper Cretaceous (Campanian) Kaiparowits Formation of southern Utah. Compared with Adocus specimens from Alberta (Zelenitsky et al. 2008), the Utah eggs are smaller and have significantly thinner eggshell, and the outer surface displays flat, rather than domed, shell units. This likely occurred because the gravid female died at an earlier stage of egg development than the Canadian specimen (Knell et al. 2011). Difley (2007) used turtle eggshell to interpret the paleoclimate of the North Horn Formation, suggesting that the abundant turtle eggshell found in lacustrine deposits represented wetter conditions.

\section{Venezuela}

[61] Late Miocene; Urumaco Formation; Falcón; ?Bairdemys venezuelensis; eggshells (Winkler and Sánchez-Villagra 2006)

Comments. See "Nests" section.

\section{Appendix 4: \\ Hierarchical Taxonomy of Turtle Ootaxa}

Testudoflexoolithidae Hirsch, 1996

Testudoflexoolithus Hirsch, 1996

Testudoflexoolithus agassizi Hirsch, 1996
Testudoflexoolithus bathonicae Buckman, 1859

Testudoolithidae Hirsch, 1996

Chelonoolithus Kohring, 1998 Chelonoolithus braemi Kohring, 1998

Emydoolithus Wang et al., 2013

Emydoolithus laiyangensis Wang et al., 2013

Haininchelys Schleich et al., 1988

Haininchelys curiosa Schleich et al., 1988

Testudoolithus Hirsch, 1996

Testudoolithus hirschi Kohring, 1999

Testudoolithus jiangi Jackson et al., 2008

Testudoolithus rigidus Hirsch, 1996

\section{Literature Cited}

ANDERSON, C. 1925. Notes on the extinct chelonian Meiolania, with a record of a new occurrence. Records of the Australian Museum 14:223-242.

ANQUETIN, J., P.M. BARRETT, M.E.H. JONES, S. MOORE-FAY AND S.E. Evans. 2009. A new stem turtle from the Middle Jurassic of Scotland: New insights into the evolution and palaeoecology of basal turtles. Proceedings of the Royal Society B 276:879-886.

AZEVEDO, S.A., V. GAllo AND J. Ferigolo. 2000. A possible chelonian egg from the Brazilian Late Cretaceous. Anais da Academia Brasileira de Ciências 72:187-193.

Barta, D.E., K.M. BrundridGe, J.A. Croghan, F.D. JaCkson, D.J. VARRICCHIO, X. JIN AND A.W. Poust. 2014. Eggs and clutches of the Spheroolithidae from the Cretaceous Tiantai basin, Zhejiang Province, China. Historical Biology 26: 183-194.

BeBiano, B.J. 1932. A Geologia do Arquipélago de Cabo Verde. Lisboa: Comunicaçōes dos Serviços Geológicos de Portugal 18:1-275.

Bertuing, M., S.J. Braddy, R.G. Bromley, G.R. Demathiteu, J. Genise, R. Mikuläš, J.K. Nielsen, K.S.S. Nielsen, A.K. RINDSGERG, M. SCHLIRF AND A. UCHMAN. 2006. Names for trace fossils: A uniform approach. Lethaia 39:265-286.

BISHOP, G.A., F.L. PIRKLE, B.K. MEYER AND W.A. PIRKLE. 2011. The foundation for sea turtle geoarchaeology and zooarchaeology: Morphology of recent and ancient sea turtle nests, St. Catherines Island, Georgia, and Cretaceous Fox Hills Sandstone, Elbert County, Colorado. In: G.A. Bishop, H.B. Rollins and D.H. Thomas, eds. Geoarchaeology of St. Catherines Island, Georgia. New York: American Museum of Natural History. pp. 247-269. (American Museum of Natural History Anthropological Papers 94.)

Braman, D.R. AND D.B. BRINKMAN. 2009. Guidebook to Geology and Palaeontology of Dinosaur Provincial Park, Alberta. Drumheller: Special Publication of the Royal Tyrrell Museum. 82 pp.

BRATTSTROM, B.H. 1961. Some new fossil tortoises from western North America with remarks on the zoogeography and paleoecology of tortoises. Journal of Paleontology 35: 543-560.

BRAY, E.S. AND K.F. HIRSCH. 1998. Eggshell from the Upper Jurassic Morrison Formation. Modern Geology 23:219-240. 
BRUNET, M. 1838. Annonce de la découverte d'os d'eléphant et d'oeufs de tortue, à Layrac près d'Agen. Bulletin de la Société géologique de France 9:252.

BUCKMAN, J. 1859. On some fossil reptilian eggs from the great oolite of Cirencester. Quarterly Journal of the Geological Society 16:107-110.

Buscalioni, A.D., M.A. Fregenal, A. Bravo, F.J. Poyato-Ariza, B. Sanchíz, A.M. Báez, O. Cambra Moo, C. Martín Closas, S.E. Evans AND J. MARUgÁN LOBON. 2008. The vertebrate assemblage of Buenache de la Sierra (Upper Barremian of Serranía de Cuenca, Spain) with insights into its taphonomy and palaeoecology. Cretaceous Research 29:687-710.

CARPENTER, K. 1999. Eggs, Nests, and Baby Dinosaurs: A Look at Dinosaur Reproduction. Indianapolis: Indiana University Press. $336 \mathrm{pp}$.

CARPENTER, K. AND K. Alf. 1994. Global distribution of dinosaur eggs, nests, and babies. In: K. Carpenter, K.F. Hirsch and J.R. Horner, eds. Dinosaur Eggs and Babies. Cambridge: Cambridge University Press. pp. 15-30.

CARRUTHERS, W. 1871. On some supposed vegetable fossils. Quarterly Journal of the Geological Society 27:443-449.

Clouse, V.R. 2001. Stratigraphy and paleogeography of dinosaur nesting grounds, Judith River Formation (Upper Cretaceous) north-central Montana: Dinosaur nesting on a tidally influenced coastal lowland plain [master's thesis]. Havre: Montana State University Northern.

Cohen, S., A. Cruickshank, K. Joysey, T. Manning and P. UPCHURCH. 1995. The Egg and Embryo Exhibition Guide. Leicester, UK: Rock Art Publishing. 16 pp.

Cox, B.M., M.G. Sumbler AND A.C. Milner. 1999. Fossilized turtle eggs from Cirencester. Proceedings of the Geologists' Association 110:267-270.

DANILOV, I.G. AND J.F. PARHAM. 2006. A redescription of 'Plesiochelys' tatsuensis from the Late Jurassic of China, with comments on the antiquity of the crown clade Cryptodira. Journal of Vertebrate Paleontology 26:573-580.

Del Campana, D. 1919. Uova fossili di chelonio nel Miocene superiore di Capudjlar press Salonicco. Bollettino della Società Geologica Italiana 38:1-6.

DIFLEY, R. 2007. Biostratigraphy of the North Horn Formation at North Horn Mountain, Embery County, Utah. In. G.C. Willis, M.D. Hylland, D.L. Clark and T.C. Chidsey Jr., eds. Central Utah-Diverse Geology of a Dynamic Landscape. Salt Lake City: Utah Geological Association. pp. 439-454. (Publication 36.)

DunN, I.C., A.B. Rodriquez-Navarro, K. MCDade, M. SCHMUTZ, R. Preisinger, D. WAdDINGTON, P.W. WiLSON AND M. BAIN. 2012. Genetic variation in eggshell crystal size and orientation is large and these traits are correlated with shell thickness and are associated with eggshell matrix protein markers. Animal Genetics 43:410-418.

England, J., M. CusaCK, N.W. Paterson, P. Edwards, M.R. LEE AND R. MARTIN. 2006. Hyperspectral cathodoluminescence imaging of modern and fossil carbonate shells. Journal of Geophysical Research 111:G03001.

Ensom, P.C. 1997. Reptile eggshell from the Purbeck Limestone Group of Dorset, southern England. Proceedings of the Dorset National History and Archaeological Society 118:79-83.

-2002. Reptile eggshell, tiny vertebrate remains and globular calcified cartilage from the Purbeck Limestone Group of southern England. Special Papers in Palaeontology 68: 203-220.

ERBEN, H.K., J. HoEFS AND K.H. WEDEPOHL. 1979. Paleobiological and isotopic studies of eggshells from a declining dinosaur species. Paleobiology 5:380-414.

ERNST, C.H. AND R.W. BARBOUR. 1989. Turtles of the World. Washington, DC: Smithsonian Institution Press. 313 pp.

EWERT, M.A. 1979. The embryo and its egg: Development and natural history. In: M. Harless and H. Morlock, eds. Turtles: Perspectives and Research. New York: John Wiley and Sons. pp. 333-413.

EwERT, M.A., S.J. FirTh AND C.E. NeLSON. 1984. Normal and multiple eggshells in batagurine turtles and their implications for dinosaurs and other reptiles. Canadian Journal of Zoology 62:1834-1841.

FAnG, X., L. Lu, Y. JiAng AND L. YANG. 2003. Cretaceous fossil eggs from the Tiantai basin of Zhenjiang, with a discussion on the extinction of dinosaurs. Geological Bulletin of China 22:512-520.

FANG, X., Z. YUE AND H. LING. 2009. Review of the past 15 years' research on fossil eggs in China. Acta Geoscientica Sinica 30:523-542.

FERNÁNDEZ, M.S. AND S.D. MATHEOS. 2011. Alteraciones en cáscaras de huevos de dinosaurios en el Cretácico superior de la Provincia de Río Negro, Argentina. Ameghiniana 48:43-52.

FernandeZ, V., E. Buffetaut, E. Maire, J. Adrien, V. SutEeTHORN AND P. TAFFOREAU. 2012. Phase contrast synchrotron microtomography: Improving noninvasive investigations of fossil embryos in ovo. Microscopy and Microanalysis 18:179-185.

FIlella-Subirà, E., Z. GAsser-Casanovas, J. Garcia-Porta AND J.A. FERRER-FERRER. 1999. Una puesta fósil de tortuga terrestre en el Pleistoceno de Formentera (Islas Pitiusas, archipiélago Balear). Treballs del Museu de Geologia de Barcelona 8:67-84.

FRAAS, E. 1913. Proterochersis, eine pleurodire Schildkröte aus dem Keuper. Jahreshefte des Vereins für vaterländische Naturkunde in Württemberg 69:13-90.

FuKUdA, Y. AND I. OBaTA. 1991. Upper Cretaceous chelonian egg from Hokkaido, Japan. Bulletin of the National Science Museum, Tokyo 17:111-118.

GAFFNEY, E.S. 1996. The postcranial morphology of Meiolania platyceps and a review of the Meiolaniidae. Bulletin of the American Museum of Natural History 229:1-165.

GafFNEY, E.S. AND P.A. MEYLAN. 1988. A phylogeny of turtles. In: M.J. Benton, ed. The Phylogeny of Classification of the Tetrapods. Oxford: Clarendon Press. pp. 157-219.

GafFNEY, E.S., P.A. MEYLAN, R.C. WoOd, E. Simons AND D.A. CAMPOS. 2011. Evolution of the side-necked turtles: The family Podocnemididae. Bulletin of the American Museum of Natural History 350:1-237.

GALE, A.S., J.M. HugGeTt AND M. GILL. 1996. The stratigraphy and petrography of the Gault Clay Formation (Albian, Cretaceous) at Redcliff, Isle of Wight. Proceedings of the Geologists' Association 107:287-298.

GarCIA, G. 2000. Diversité des coquilles "minces" d'oeufs fossiles du Crétacé supérieur du sud de la France. Geobios 33:113-126.

Garcla-TaLAVERA, F. 1990. Aves gigantes en el Mioceno de Famara (Lanzarote). Revista de la Academia Canaria de Ciencias 2:71-79. 
Gergens, F. 1860. Tertiäre Schildkröteneier zu Oppenheim. Neues Jahrbuch für Mineralogie, Geognosie, Geologie und Petrefaktenkunds 1860:554-555.

GRELLET-TINNER, G. 2006. Phylogenetic interpretation of eggs and eggshells: Implications for phylogeny of Paleognathae. Alcheringa 30:141-182.

Grellet-Tinner, G. and L.M. Chiappe. 2004. Dinosaur eggs and nesting: Implications for understanding the origins of birds. In: P.J. Currie, E.B. Koppelhus, M.A. Shugar and J.L. Wright, eds. Feathered Dragons: Studies on the Transition from Dinosaurs to Birds. Indianapolis: Indiana University Press. pp. 185-214.

Grellet-Tinner, G., F. Corsetti ANd A.D. Buscaloni. 2010. The importance of microscopic examinations of eggshells: Discrimination of bioalteration and diagenetic overprints from biological features. Journal of Iberian Geology 36:181-192.

Grellet-Tinner, G., X. Murelaga, J.C. Larrasoaña, L.F. Silverra, M. Olivares, L.A. Ortega, P.W. Trimby and A. PasCUAL. 2012. The first occurrence in the fossil record of an aquatic avian twig-nest with Phoenicopteriformes eggs: Evolutionary implications. PLoS ONE 7:1-14.

GulKO, D. AND K. ECKERT. 2004. Sea turtles: An ecological guide. Honolulu: Mutual Publishing. $121 \mathrm{pp}$.

HAY, O.P. 1908. The Fossil Turtles of North America. New York: Carnegie Institution of Washington. $568 \mathrm{pp}$.

HELMDACH, F. 1971. Stratigraphy and ostracod-fauna from the coalmine Guimarota (Upper Jurassic). Serviços Geológicos de Portugal 17:41-88.

HEMPRICH, A. 1932. Fossile Gelege der Sumpfschildkröte in diluvialen Sü wasser-Kalken bei Halberstadt. Das Aquarium 5:78-80.

HIRSCH, K.F. 1983. Contemporary and fossil chelonian eggshells. Copeia 1983:382-397.

-1989. Interpretations of Cretaceous and pre-Creatceous eggs and shell fragments. In: D.D. Gillette and M.G. Lockley, eds. Dinosaur Tracks and Traces. Cambridge: Cambridge University Press. pp. 89-97.

-1996. Parataxonomic classification of fossil chelonian and gecko eggs. Journal of Vertebrate Paleontology 16:752762.

HIRSCH, K.F. AND E.S. BRAY. 1988. Spheroidal eggs-avian and chelonian-from the Miocene and Oligocene of the western interior. Hunteria 1:1-8.

HIRSCH, K.F. AND L.F. LOPEZ-JURADO. 1987. Pliocene chelonian fossil eggs from Gran Canaria, Canary Islands. Journal of Vertebrate Paleontology 7:96-99.

HIRSCH, K.F. AND M.J. PACKARD. 1987. Review of fossil eggs and the shell structure. Scanning Microscopy 1:383-400.

HIRSCH, K.F., R.G. Young AND H.J. ARMSTRONG. 1987. Eggshell fragments from the Jurassic Morrison Formation of Colorado. In: W.R. Averett, ed. Paleontology and Geology of the Dinosaur Triangle. Grand Junction, CO: Museum of Western Colorado. pp. 79-84.

HUH, M. AND D.K. ZELENITSKY. 2002. Rich dinosaur nesting site from the Cretaceous of Bosung County, Chullanam-Do Pronvince, South Korea. Journal of Vertebrate Paleontology 22:716-718.

HumMeL, K. 1929. Die fossilen Weichschildkröten (Trionychia). Jena: Gustav Fischer Verlag. 124 pp.

HUTterer, R, F. GaRCiA-TALAVERA, N. LOPEZ-MARTINEZ AND J. MICHAUX. 1997. New chelonian eggs from the Tertiary of Lan- zarote and Fuerteventura, and a review of fossil tortoises of the Canary Islands (Reptilia, Testuinidae). Vieraea 26:139-161.

[ICZN] INTERNATIONAL COMMISSION ON ZOOLOGICAL NOMENCLATURE. 1999. International Code of Zoological Nomenclature. London: The International Trust for Zoological Nomenclature. $306 \mathrm{pp}$.

IsaI, S., A. Matsushita and R. Hirayama. 2006. Chelonian eggshells from the Lower Cretaceous Kuwajima Formation of the Tetori Group, central Japan. Paleontological Research 10:29-36.

IVERSON, J.B. AND M.A. EwERT. 1991. Physical characteristics of reptilian eggs and a comparison with avian eggs. In: D.C. Deeming and M.W.J. Ferguson, eds. Egg Incubation: Its Effects on Embryonic Development in Birds and Reptiles. New York: Cambridge University Press. pp. 88-100.

JACKSON, F.D., J.R. HORNER AND D.J. VARRICCHIO. 2010. A study of Troodon egg containing embryonic remains using epifluorescence microscopy and other techniques. Cretaceous Research 31:255-262.

JACKSON, F.D., X. JIN AND J.G. SCHMITT. 2009. Fungi in a Lower Cretaceous turtle egg from China: Evidence of ecological interactions. Palaios 24:840-845.

JACKSON, F.D., X. Jin, D.J. VARRICCHIO, Y. AZUMA AND Y. JiANG. 2008. The first in situ turtle clutch from the cretaceous Tiantai Basin, Zhenjiang Province, China. Journal of Vertebrate Paleontology 28:319-325.

JACKSON, F.D. AND J.G. SCHMITT. 2008. Recognition of vertebrate egg abnormalities in the Upper Cretaceous fossil record. Cretaceous Research 29:27-39.

JACKSON, F.D., M.H. SCHWEITZER AND J.G. SCHMitr. 2002. Dinosaur eggshell study using scanning electron microscopy. Scanning 24:217-223.

JAIN, S.L. 1989. Recent dinosaur discoveries in India, including eggshells, nests and coprolites. In: D.D. Gillette and M.G. Lockley, eds. Dinosaur Tracks and Traces. Cambridge: Cambridge University Press. pp. 99-108.

Jin, X., F.D. JACKSON, D.J. VARRICCHIO, Y. AZUMA AND T. HE. 2010. The first Dictyoolithus egg clutches from the Lishui Basin, Zhenjiang Province, China. Journal of Vertebrate Paleontology 30:188-195.

JOYCE, W.G. 2007. Phylogenetic relationships of Mesozoic turtles. Bulletin of the Peabody Museum of Natural History 48(1):3-102.

JOYCE, W.G., N. MickLiCH, S.F.K. SCHAAL AND T.M. SCHEYER. 2012. Caught in the act: The first record of copulating fossil vertebrates. Biology Letter 1-4.

JOYCE, W.G., J.F. PARHAM, T.R. LYSON, R.C.M. WARNOCK AND P.C.J. DONOGHUE. 2013. A divergence dating analysis of turtles using fossil calibration: An example of best practices. Journal of Paleontology 87:612-634.

JOYCE, W.G., R.R. SCHOCH AND T.R. LYsON. 2013. The girdles of the oldest fossil turtle, Proterochesis robusta, and the agge of the turtle crown. BMC Evolutionary Biology 13:1-9.

JoYCE, W.G. AND D.K. ZELENITSKY. 2002. Turtle egg pseudomorphs from the Late Jurassic of Schamhaupten, Germany. Archaeopteryx 20:57-62.

KIM, C., J. KIM AND M. HUH. 2008. Age and stratification of dinosaur eggs and clutches from Seonso Formation, South Korea. Journal of Korean Earth Science Society 29:386-395. KNel, M.J., F.D. Jackson, A.L. Titus and L.B. AlbRight III. 2011. A gravid fossil turtle from the Upper Cretaceous 
(Campanian) Kaiparowits Formation, southern Utah. Historical Biology 23:57-62.

KoHrInG, R. 1990a. Fossile Reptile-Eischalen (Chelonia, Crocodilia, Dinosauria) aus dem unteren Barremium von Galve (Provinz Teruel, SE-Spanien). Paläontologische Zeitschrift 64:329-344.

-1990b. Reptilien-Eischalen aus dem Oberjura und der Unterkreide von Portugal und Spanien. Nachrichten der Deutschen Geologischen Gesellschaft 43:53-54.

-1990 c. Upper Jurassic chelonian eggshell fragments from the Guimarota Mine (central Portugal). Journal of Vertebrate Paleontology 10:128-130.

-1993. Fossile Schildkröteneier aus dem Miozän von SaintGérand-le-Puy (Frankreich). Neues Jahrbuch für Geologie und Paläontologie, Monatshefte 12:705-712.

-1998a. Neue Schlidkröten-Eischalen aus dem Oberjura der Grube Guimarota (Portugal). Berliner Geowissenschaftliche Abhandlungen 28:113-117.

$-1998 \mathrm{~b}$. Schildkröten und Vogeleischalen aus dem Untermiozän (MN4b) von Donice (Tschechien). Documenta naturae 122:49-57.

-1999a. Calcified shell membranes in fossil vertebrate eggshell: Evidence for preburial diagenesis. Journal of Vertebrate Paleontology 19:723-727.

-1999 b. Strukturen, Biostratinomie, systematische und phylogenetische Relevanz von Eischalen amnioter Wirbeltiere. Courier Forschungsinstitut Senckenberg 210:1-640.

-2000 . Eggshells from the Guimarota mine. In: T. Martin and B. Krebs, eds. Guimarota: A Jurassic Ecosystem. Munich: Verlag Dr. Friedrich Pfeil. pp. 87-90.

Kowaluis, B.J., E.H. Christiansen AND A.L. Deino. 1991. Age of the Brushy Basin Member of the Morrison Formation, Colorado Plateau, western USA. Cretaceous Research 12:483-493.

KuChling, G. 1999. The Reproductive Biology of the Chelonia. Berlin: Springer. 223 pp.

KunTZ, P. 1981. Des oeufs fossilisés. Minéraux et Fossiles 7:18-20.

LAWVER, D.R. 2012. Fossil and modern turtle eggshell: Testing the validity of eggshell characters in cladistics analyses. In: Program and Abstracts of the 72nd Annual Meeting of the Society of Vertebrate Paleontology. Journal of Vertebrate Paleontology 32(Suppl 2):126.

-2013. The first occurrence of fossil eggs from the Upper Cretaceous (Campanian) Morondava Basin, Madagascar. In: Program and Abstracts of the 73nd Annual Meeting of the Society of Vertebrate Paleontology; 2013 Oct 30-Nov 2; Los Angeles, CA. Bethesda, MD: Society of Vertebrate Paleontology. p. 160.

LEE, Y. 2003. Dinosaur bones and eggs in South Korea. Memoir of the Fukui Prefectural Dinosaur Museum 2:113-121.

LOCKLEY, M.G. AND D.D. GILLETTE. 1989. Dinosaur tracks and traces: An overview. In: D.D. Gillette and M.G. Lockley, eds. Dinosaur Tracks and Traces. Cambridge: Cambridge University Press. pp. 99-108.

LOPEZ-JURADO, L.F. 1985. Los reptiles fósiles de la Isla de Gran Canaria (Islas Canarias). Bonner Zoologische Beiträge 36:355-364.

MACAU-VILAR, F. 1958. Contribución al estudio del Mioceno Canario. Boletín Real de la Sociedad Española de Historia Natural 56:477-486.

MARTIN, A.J. 2001. Introduction to the Study of Dinosaurs. Oxford: Blackwell Publishing. 560 pp.
-2013. Life Traces of the Georgia Coast. Bloomington: Indiana University Press. $670 \mathrm{pp}$.

MASSE, P.J. 1989. A chelonian egg from the Vraconian of south east France, paleogeographic implications. Geobios 22:523-530.

MCGEE, A.R. 2012. A fossilized turtle egg clutch with embryos from the Upper Cretaceous Oldman Formation, southeastern Alberta: Description, taxonomic identity, and embryonic staging [master's thesis]. Calgary: University of Calgary.

MEYER, H. 1860. Trionyx Eier im Mainzer Becken. Jahrbuch fur Mineralogie, Geologie und Palaeontologie 1860:554-555.

MEYLAN, P.A. AND E.S. GAFFNEY. 1989. The skeletal morphology of the Cretaceous cryptodiran turtle, Adocus, and the relationships of the Trionychoidea. American Museum Novitates 2941:1-60.

Mikhailov, K.E. 1992. The microstructure of avian and dinosaurian eggshell: Phylogenetic implications. Natural History Museum of Los Angeles County 38:361-373.

-1997 . Fossil and recent eggshell in amniotic vertebrates: Fine structure, comparative morphology and classification. Special Papers in Paleontology 56:1-80.

MikHaILOV, K.E., E.S. BRAY AND K.F. HirSCH. 1996. Parataxonomy of fossil egg remains (Veterovata): Principles and applications. Journal of Vertebrate Paleontology 16:763-769.

MiKhaIlov, K.E., K. SabatH and S. KurZanOv. 1994. Eggs and nests from the Cretaceous of Mongolia. In: K. Carpenter, K.F. Hirsch and J.R. Horner, eds. Dinosaur Eggs and Babies. Cambridge: Cambridge University Press. pp. 88-115.

MoHABEY, D.M. 1998. Systematics of Indian Upper Cretaceous dinosaur and chelonian eggshells. Journal of Vertebrate Paleontology 18:348-362.

Moreno-Azanza, M., J.M. Gasca and J.I. Canudo. 2008. Fragmentos de cáscara de huevo del tipo básico Testudoide del Cretácico Inferior de Zaragoza (Formación Villanueva de Huerva, Hauteriviense-Valanginiense). Palaeontologica Nova 8:305-315.

-2009 . New data on the Valanginian-Hauterivian reptile ootaxa of the Iberian Range (NE of Spain). In: P. Godefroit and O. Lambert, eds. European Association of Vertebrate Palaeontologists (EAVP) Extraordinary Meeting: Tribute to Charles Darwin and Bernissart Iguanodons: New Perspectives on Vertebrate Evolution and Early Cretaceous Ecosystems; 2009 Feb 9-13; Brussels, Belgium. Brussels, Belgium: Royal Belgian Institute of Natural Sciences. p. 72.

Moreno-Azanza, M., J.M. Gasca, I. Diaz-Martínez, A. FerNÁNDEZ, J.I. CANUdD AND F. PéreZ-LORENTE. 2013. Ootaxa assemblage from El Horcajo site (upper Berriasian, Cameros Basin) in Trevijano (La Rioja, Spain). In: F. Torcida Fernández-Baldor and P. Huerta, eds. VI Jornadas Internacionales sobre Paleontología de Dinosaurios y su entorno; 2013 Sept 5-7; Burgos, Spain. Burgos, Spain: Colectivo Arqueológico y Paleontológico de Salas, C.A.S. pp. 93-95.

Moreno-AZanza, M., E. Mariani, B. BaUluz AND J.I. CANUdo. 2013. Growth Mechanisms in dinosaur eggshells: An insight from electron backscatter diffraction. Journal of Vertebrate Paleontology 33:121-130.

Mueller-TÖWE, I.J., T.A. KJelDAHL-VALLON, J. MILAN, L.H. VALLON, G. THEODOROU, J. LINDGREN, S.J. ROUSSIAKIS AND R.G. BROMLEY. 2011. First chelonian eggs and carapace fragments from the Pliocene of Rhodes, Greece. Neues Jahrbuch für Geologie und Paläontologie, Abhandlungen 262:309-322. 
NAVA, W.R. AND A.G. Martinelli. 2011. A new squamate lizard from the Upper Cretaceous Adamantina Formation (Bauru Group), São Paulo State, Brazil. Anais da Academia Brasileira de Ciências 83:291-299.

OBata, I., H. YoshiKaZu and O. HiroyukI. 1972. Preliminary report on the Cretaceous reptile fossils from Hokkaido. Memoirs of the National Science Museum, Tokyo 5:213-222.

PAIK, L.S., H.J. KIM AND M. HUH. 2012. Dinosaur egg deposits in the Cretaceous Gyeongsang Supergroup, Korea: Diversity and paleobiological implications. Journal of Asian Earth Sciences 56:135-146.

QUINN, B. 1994. Fossilized eggshell preparation. In: P. Leiggi and P. May, eds. Vertebrate Paleontological Techniques, Volume 1. New York: Cambridge University Press. pp. 146-153.

Riding, J.B., I.E. PENN AND R. WoOlLAM. 1985. Dinoflagellate cysts from the type area of the Bathonian stage (Middle Jurassic; southwest England). Review of Palaeobotany and Palynology 45:149-169.

Rodriguez-Navarro, A.B., A. Yebra, Y. Nys, C. JimenezLOPEZ AND J.M. GarCia-RUIZ. 2007. Analysis of avian eggshell microstructure using X-ray area detectors. European Journal of Mineralogy 19:391-398.

ROTHE, P. AND K. KLEMMER. 1991. Fossil eggs of the terrestrial tortoises (Family Testudinidae) from Pliocene calcarenites of Fuerteventura (Canary Islands, Spain). Senckenbergiana lethaea 71:307-317.

Rutz-OMenaca, J.I., J.I. Canudo, M. Aurell, B. Bádenas, J.L. Barco, G. CuenCA-Bescós and J. Ipas. 2004. Estado de las investigaciones sobre los vertebrados del Jurásico Superior y Cretácico Inferior de Galve (Teruel). Estudios Geológicos 60:179-202.

SAHNI, M.R. 1957. A fossil reptilian egg from the Uttatturs (Cenomanian) of Southern India, being the first record of a vertebrate fossil egg in India. Records of the Geological Survey of India 87:671-674.

SANDER, P.M. 2012. Reproduction in early amniotes. Science 337:806-808.

SCHLEICH, H.H. AND W. KäSTLE. 1988. Reptile Egg-Shells: SEM Atlas. Stuttgart: Gustav Fischer. 123 pp.

SCHLEICH, H.H., W. KÄSTLE AND M.G. vAN DYCK. 1988. Paläogene Eischalenreste von Hainin (Belgien). Paläontologische Zeitschrift 62:133-146.

SCHWEITZER, M.H., F.D. JACKSON, L.M. CHIAPPE, J.G. SCHMTrT, J.O. CALVO AND D.E. RuBILAR, 2002. Late Cretaceous avian eggs with embryos from Argentina. Journal of Vertebrate Paleontology 22:191-195.

SimPson, S. 1975. Classification of trace fossils. In: R.W. Frey, ed. The Study of Trace Fossils: A Synthesis of Principles, Problems, and Procedures in Ichnology. Berlin: SpringerVerlag. pp. 39-54.

Sochava, A.V. 1971. Two types of eggshell in Senonian dinosaurs. Paleontological Journal 5:353-361.

SpOtILA, J.R. 2004. Sea Turtles: A Complete Guide to Their Biology, Behavior, and Conservation. Baltimore: Johns Hopkins University Press. 228 pp.
TANAKA, K., D.K. Zelentissky, T. WILliamson, A. WeIl and F. THERRIEN. 2011. Fossil eggshells from the Upper Cretaceous (Campanian) Fruitland Formation, New Mexico. Historical Biology 23:41-55.

TYLER, C. 1969. Avian egg shells: Their structure and characteristics. International Review of General and Experimental Zoology 4:81-130.

VAN STRAelen, V. 1928. Les oeufs de reptiles fossiles. Palaeobiologica 1:295-312.

VARRICCHIO, D.J. AND F.D. JACKSON. 2004. A phylogenetic assessment of prismatic dinosaur eggs from the Cretaceous Two Medicine Formation of Montana. Journal of Vertebrate Paleontology 24:931-937.

VARRICCHIO, D.J., F.D. JACKSON AND C.N. TRUEMAN. 1999. A nesting trace with eggs for the Cretaceous theropod dinosaur Troodon formosus. Journal of Vertebrate Paleontology 19:91-100.

VARricCHIO, D.J., D. Simon, S. OSER, D. LAWVER AND F. JACKSON. 2011. Dinosaur eggs in space and time. In: Program and Abstract of the 71st Annual Meeting of the Society of Vertebrate Paleontology. Journal of Vertebrate Paleontology 31(Suppl 2):209.

WANG, Q., X. WANG, Z. ZhOA, J. Zhang AND S. Jiang. 2013. New turtle egg fossil from the Upper Cretaceous of the Laiyang Basin, Shandong Province, China. Annals of the Brazilian Academy of Sciences 85:103-111.

WINKLER, J.D. 2006. Testing phylogenetic implications of eggshell characters in side-necked turtles (Testudines: Pleurodira). Zoology 109:127-136.

WINKLER, J.D. AND M.R. SÁNCHEZ-VILLAGRA. 2006. A nesting site and egg morphology of a Miocene turtle from Urumaco, Venezuela: Evidence of marine adaptations in pelomedusoides. Palaeontology 49:641-646.

YABE, H. AND K. OZAKI. 1929. Fossil chelonian (?) eggs from south Manchuria. Proceedings of the Imperial Academy 5:42-45.

YANG, S.Y., J.D. LIM, I.S. PAIK, M. HUH, S.J. SEO AND K.G. HWANG. 2006. Research Report on the Excavation of Dinosaur and Turtle Eggs from the Dinosaur and Bird Footprint Sites at Deakmyeongri, Goseong County, Korea. Research Group of Geology and Paleontology of Korea. 113 pp.

ZELENTTSKY, D.K. 1995. Fossil eggs and eggshell fragments from the Oldman Formation (Upper Cretaceous; Campanian), Southern Alberta, Canada [dissertation]. Calgary: University of Calgary.

ZELENTTSKY, D.K. AND S.P. MODESTO. 2003. New information on the eggshell of ratites (Aves) and its phylogenetic implications. Canadian Journal of Zoology 81:962-970.

Zelenitsky, D.K., F. TherRien, W.G. JOYCE AND D.B. BRINKMAN. 2008. First fossil gravid turtle provides insight into the evolution of reproductive traits in turtles. Biology Letters 4:715-718.

ZHANG, S. 2009. Geological Formation Names of China (1866-2000). Berlin: Springer. 1784 pp.

Editor's note: This article is intended to be included with others in a forthcoming book being coordinated by Walter G. Joyce to elucidate the fossil record of turtles. The individual articles that will form the components of this book are being published separately in the next several volumes of the Bulletin of the Peabody Museum of Natural History. 